\title{
The influence of local oil exploration and regional wildfires on summer 2015 aerosol over the North Slope of Alaska
}

\author{
Jessie M. Creamean ${ }^{1,2}$, Maximilian Maahn ${ }^{1,2}$, Gijs de Boer ${ }^{1,2}$, Allison McComiskey ${ }^{3}$, Arthur J. Sedlacek ${ }^{4}$, and \\ Yan Feng 5 \\ ${ }^{1}$ Cooperative Institute for Research in Environmental Sciences, University of Colorado, Boulder, CO, USA \\ ${ }^{2}$ Physical Sciences Division, National Oceanic and Atmospheric Administration, Boulder, CO, USA \\ ${ }^{3}$ Global Monitoring Division, National Oceanic and Atmospheric Administration, Boulder, CO, USA \\ ${ }^{4}$ Environmental and Climate Sciences, Brookhaven National Laboratory, Upton, NY, USA \\ ${ }^{5}$ Environment Science Division, Argonne National Laboratory, Lemont, IL, USA
}

Correspondence: Jessie M. Creamean (jessie.creamean@noaa.gov)

Received: 27 June 2017 - Discussion started: 6 July 2017

Revised: 4 December 2017 - Accepted: 5 December 2017 - Published: 18 January 2018

\begin{abstract}
The Arctic is warming at an alarming rate, yet the processes that contribute to the enhanced warming are not well understood. Arctic aerosols have been targeted in studies for decades due to their consequential impacts on the energy budget, both directly and indirectly through their ability to modulate cloud microphysics. Even with the breadth of knowledge afforded from these previous studies, aerosols and their effects remain poorly quantified, especially in the rapidly changing Arctic. Additionally, many previous studies involved use of ground-based measurements, and due to the frequent stratified nature of the Arctic atmosphere, brings into question the representativeness of these datasets aloft. Here, we report on airborne observations from the US Department of Energy Atmospheric Radiation Measurement (ARM) program's Fifth Airborne Carbon Measurements (ACME-V) field campaign along the North Slope of Alaska during the summer of 2015. Contrary to previous evidence that the Alaskan Arctic summertime air is relatively pristine, we show how local oil extraction activities, 2015's central Alaskan wildfires, and, to a lesser extent, long-range transport introduce aerosols and trace gases higher in concentration than previously reported in Arctic haze measurements to the North Slope. Although these sources were either episodic or localized, they serve as abundant aerosol sources that have the potential to impact a larger spatial scale after emission.
\end{abstract}

\section{Introduction}

The Arctic is warming rapidly compared to other locations globally, which has implications for anomalous snow and ice melt (Jeffries et al., 2013). Replacement of highly reflective surfaces by darker, more absorbing surfaces (i.e., tundra and open ocean water) enhances Arctic warming, especially in summer (Chapin et al., 2005). Such warming subsequently impacts the ecological cycle, socioeconomics, and mid-latitude weather patterns (Screen and Simmonds, 2010; Serreze and Barry, 2011). This warming feedback is one in a complex system of interrelated processes resulting in "Arctic amplification", the observed enhanced warming seen in the Arctic to date, and in part motivates the need to improve our understanding of atmospheric processes that modulate energy reaching the Arctic surface (Serreze and Francis, 2006).

In addition to the ice-albedo feedback described above, the principal atmospheric constituents that perturb the surface energy budget are clouds and aerosols (Tsay et al., 1989). Aerosols can directly scatter and absorb solar radiation or indirectly impact atmospheric radiation through their roles in the modulation of cloud microphysics by serving as cloud condensation nuclei $(\mathrm{CCN})$ or ice nucleating particles (INPs) (Boucher et al., 2013). However, the ability of aerosols to serve as CCN or INPs depends on their composition, size, and number concentration, each of which depends on their source and extent of aging. Several previous studies have focused on examining the sources of Arctic aerosols, including ground-based and airborne research campaigns con- 
ducted in the Alaskan Arctic extending back to the mid-20th century (e.g., Schnell and Raatz, 1984; Barrie, 1986; Delene and Ogren, 2002; Quinn et al., 2002, 2009; Verlinde et al., 2007; Brock et al., 2011; McFarquhar et al., 2011). To better understand aerosol properties in this environment, two atmospheric research facilities have been established on the North Slope of Alaska that encompass routine, aerosol measurements - including, but not limited to, aerosol optical, physical, and chemical properties, and CCN concentrations.

Utqiagvik, Alaska (formally Barrow), features an observatory established by the National Oceanic and Atmospheric Administration (NOAA) Earth System Research Laboratory's (ESRL) Global Monitoring Division (GMD) in 1976. Previous work at this facility involves different combinations of the long-term, ground-based aerosol optical, physical, and chemical property measurements to evaluate the annual cycle of aerosol sources at Utqiagivik (e.g., Polissar et al., 2001; Delene and Ogren, 2002; Quinn et al., 2002, 2009). For example, Quinn et al. $(2002,2009)$ used aerosol number concentrations, optical properties, and chemistry measurements to conclude that the winter and spring are impacted by aerosol transported from mid-latitudes, while summer and fall aerosols contain contributions from local biological activity, sea salt, and residual (i.e., unanalyzed) aerosol mass that may represent mineral or organic species. More recently, Kolesar et al. (2017) used a 6-year time series of particle size distributions to conclude that particle growth events occurring at Utqiagivik resulted from gasphase emissions originating from the oil fields of the Prudhoe Bay area, approximately $300 \mathrm{~km}$ east of Utqiagivik. Gunsch et al. (2017) found submicron (i.e., $<1 \mu \mathrm{m}$ in diameter) combustion-derived particles were transported from the Prudhoe Bay oil field to Utqiagvik $10 \%$ of the time during August-September 2015. In addition to Utqiagivik, another northern Alaskan facility was recently established by the US Department of Energy (DOE) Atmospheric Radiation Measurement (ARM; since 2013) program at Oliktok Point (https://dis.arm.gov/sites/amf/oli/). This site is located in the northwest region of oil extraction activities in Prudhoe Bay, making it an ideal location to determine the potential impacts of emissions from such activities on the relatively pristine Arctic atmosphere. Aerosol optical, physical, and chemical property measurements were implemented during the summer of 2016. Overall, the North Slope provides a unique opportunity to investigate aerosols and their impacts from the clean Arctic background, long-range transport from lower latitudes, and regional oil extraction activities.

While previous studies have provided significant insights into aerosol properties in northern Alaska, one crucial deficiency is that most of them comprise only ground-based observations of aerosol (e.g., Barrie, 1986; Polissar et al., 2001; Delene and Ogren, 2002; Quinn et al., 2002, 2009; Gunsch et al., 2017; Kolesar et al., 2017). The Arctic atmosphere can be highly stratified (Persson et al., 2002; Graversen et al., 2008), thus hindering vertical transport of aerosols from their surface sources. Accordingly, numerous airborne campaigns have focused on evaluating sources of mid- to upper-tropospheric aerosol and aerosol-cloud interactions. For example, during the March 1983 NOAA Arctic Gas and Aerosol Sampling Program (AGASP) flights over Alaska, aerosol number concentrations were found to vary substantially over the vertical extent of the flight region (Schnell and Raatz, 1984). Several airborne campaigns - including Aerosol, Radiation, and Cloud Processes affecting Arctic Climate (ARCPAC), Arctic Research of the Composition of the Troposphere from Aircraft and Satellites (ARCTAS-A), and Indirect and Semi-direct Aerosol Campaign (ISDAC) took place in the region during April 2008 to characterize tropospheric pollution and its source contributions to the Arctic haze season during the International Polar Year (Brock et al., 2011; McFarquhar et al., 2011; Bian et al., 2013). These studies presented valuable information on the vertical structure of Arctic aerosol, and the relative contributions from Arctic background, fossil fuels, and biomass burning sources but are limited to April or March only. Airborne measurements available from the Mixed-Phase Arctic Cloud Experiment (M-PACE), which took place from late September to late October 2008, were predominantly focused on clouds and, with respect to aerosols, only encompassed aerosol size distribution measurements and INP concentrations (Verlinde et al., 2007; Prenni et al., 2009; Jackson et al., 2012). To our knowledge, only one study reports airborne in situ aerosol measurements over the Alaskan Arctic during summer: NASA's 1988 Arctic Boundary Layer Experiment (ABLE 3A) (Gregory et al., 1992). However, this study was limited to flights between Fairbanks and Utqiagivik and to aerosol size distributions from 0.12 to $8 \mu \mathrm{m}$ in diameter - no other aerosol measurements were obtained.

In the context of warming temperatures, emissions from oil extraction, added shipping routes due to a reduction in sea ice extent, and wildfires are expected to increase in subArctic boreal regions (Randerson et al., 2006; Gautier et al., 2009; Harsem et al., 2011; Peters et al., 2011; de Groot et al., 2013; Roiger et al., 2015). Thus, regional fossil fuel and biomass burning combustion sources will further contribute to the aerosol population may serve as an increasingly crucial source of aerosol in the future. However, local pollution and other high-latitude Eurasian resource extraction sources and their resulting impacts on clouds and radiation are poorly quantified (Arnold et al., 2016). Hobbs and Rangno (1998) documented increased cloud droplet number concentrations in air masses originating around Prudhoe Bay through airborne measurements over the Beaufort Sea. In a companion paper by Maahn et al. (2017), local emissions from Prudhoe Bay were shown to impact cloud drop size in comparison with more pristine clouds over Utqiagivik. Such studies support the idea that emissions from oil extraction activities in this region have air quality and climatic implications and are important to assess. Additionally, Stohl et al. (2013) reported that gas flaring emissions are underestimated in the Arctic, 
further justifying the need to evaluate emissions from these sources.

In addition to industrial sources, it is recognized that Alaskan boreal fires periodically influence the aerosol population over the North Slope. Eck et al. (2009) reported high summertime (August) fire counts, impacting aerosol optical depths (AODs) over Utqiagivik. Stohl et al. (2006) reported similar findings using ground-based absorption and $\mathrm{CO}$ (i.e., a tracer for biomass burning) measurements at Utqiagivik. Both studies concluded that individual smoke transport events resulted in short episodes of higher AOD and absorption values than typical springtime Arctic haze. Regardless of their episodic behavior, summertime sub-Arctic boreal fires can produce substantial quantities of aerosol that can reside in the troposphere for 1-2 weeks (Stohl et al., 2013). The Arctic summertime atmosphere is historically less polluted as compared to the rest of the year (Quinn et al., 2002; Leaitch et al., 2013; Heintzenberg et al., 2015); thus it is critical to assess the impacts of potentially important local sources of summertime aerosol on Arctic radiation and cloud microphysical processes. Here, we present aerosol and trace gas observations from ARM's Fifth Airborne Carbon Measurements (ACME-V) field campaign to evaluate local sources during the summer of 2015 in the Alaskan Arctic.

\section{Methods}

\subsection{Study location and dates}

ACME-V flights were conducted over the North Slope of Alaska between five waypoints, including Oliktok Point $\left(70.51^{\circ} \mathrm{N}, 149.86^{\circ} \mathrm{W}\right)$, Utqiagivik $\left(71.29^{\circ} \mathrm{N}\right.$, $\left.156.79^{\circ} \mathrm{W}\right)$, Atqasuk $\left(70.48^{\circ} \mathrm{N}, 157.42^{\circ} \mathrm{W}\right)$, Ivotuk $\left(68.49^{\circ} \mathrm{N}, \quad 155.75^{\circ} \mathrm{W}\right)$, and Toolik Lake $\left(68.63^{\circ} \mathrm{N}\right.$, $\left.149.61^{\circ} \mathrm{W}\right)$ (Fig. 1), all north of the Brooks Mountain Range. The campaign involved 38 research flights from 4 June to 9 September 2015, generally flying every 2-3 days (Table 1). The DOE ARM Gulfstream-1 (G-1; part of the ARM Aerial Facility) aircraft typically flew below $1000 \mathrm{~m}$ above ground level (ma.g.l.) between the waypoints, while spiralling up to $8000 \mathrm{ma.g}$.l. above each waypoint. Data altitudes were converted to meters above mean sea level (ma.m.s.l.) for a more direct comparison between measurement locations. Flight tracks varied in the number and order of waypoints that were overflown.

\subsection{Aircraft aerosol and trace gas payload}

The G-1 was equipped with a suite of atmospheric state, cloud, aerosol, and trace gas instruments (see https://www. arm.gov/research/campaigns/aaf2014armacmev for a complete list of instrumentation and available data) (Biraud et al., 2016), though in the current study we only focus on the aerosol, $\mathrm{CO}$, and $\mathrm{CO}_{2}$ measurements. Total number concentrations $(\mathrm{CN})$ of aerosol particles $3 \mathrm{~nm}-3 \mu \mathrm{m}$ and
$10 \mathrm{~nm}-3 \mu \mathrm{m}$ in diameter $\left(D_{\mathrm{p}}\right)$ were measured using two condensation particle counters (CPCs, TSI, Inc. models 3025 and 3010, respectively). The model 3025 and 3010 CPCs have a $50 \%$ counting efficiency of 3 and $10 \mathrm{~nm}$ particles, respectively. Aerosol size distributions were measured using three different instruments, including an ultrahigh-sensitivity aerosol sizer (UHSAS, Droplet Measurement Technologies, Inc.), a passive cavity aerosol spectrometer (PCASP, Droplet Measurement Technologies, Inc. model SPP-200), and an optical particle counter (OPC, Climet model C1-3100) in combination with a multi-channel analyzer (Ortec model Easy-MCA-8k), which measured particle optical diameters in the ranges of $0.06-1 \mu \mathrm{m}, 0.1-3 \mu \mathrm{m}$, and $0.8-15 \mu \mathrm{m}$, respectively. The PCASP was operated with an anti-ice heater, thus the particles measured are predominantly dry (Kassianov et al., 2015). The UHSAS experienced instrumental complications during most of the campaign; thus is not used for the current study to alleviate any limitations and skewness from operation dates. Total aerosol light scattering and absorption coefficients $\left(\mathrm{Mm}^{-1}\right)$ were measured using a three-wavelength $(450,550$, and $700 \mathrm{~nm})$ nephelometer (TSI, Inc. model 3563) and three-wavelength (464, 528, and $648 \mathrm{~nm}$ ) particle soot absorption photometer (PSAP, Radiance Research, Inc.), respectively. Refractory black carbon ( $\mathrm{rBC}$ ) concentrations were measured with the single-particle soot photometer (SP2, Droplet Measurement Technologies, Inc.). The SP2 measures individual rBC particles through laser-induced incandescence, making it selective for rBC (Sedlacek, 2016). Quality assurance/quality control (QA/QC) checks of the SP2 data ensure that other potentially refractive particles such as mineral dust are not counted as $\mathrm{rBC}$ particles. $\mathrm{CO}$ concentrations were measured with a $\mathrm{CO} / \mathrm{N}_{2} \mathrm{O} / \mathrm{H}_{2} \mathrm{O}$ instrument (Los Gatos integrated cavity output spectroscopy, model 907-0015-0001) and is used as a tracer for combustion sources, including both biomass burning and fossil fuel combustion (Andreae and Merlet, 2001; Brock et al., 2011; Liu et al., 2014). $\mathrm{CO}_{2}$ concentrations were measured by cavity ring-down spectroscopy (Picarro model G2301) and together with the $\mathrm{CO}$ measurements were used to calculate modified combustion efficiency (MCE) (Liu et al., 2014; Biraud and Reichl, 2016). MCE is defined as $\Delta \mathrm{CO}_{2} /\left(\Delta \mathrm{CO}_{2}+\Delta \mathrm{CO}\right)$ where $\Delta \mathrm{CO}_{2}$ and $\Delta \mathrm{CO}$ indicate the increase from background $\mathrm{CO}_{2}$ and $\mathrm{CO}$ concentrations, respectively (Liu et al., 2014), and was calculated for data in which fires impacted the measurements. Background $\mathrm{CO}_{2}$ and $\mathrm{CO}$ concentrations of 383 and 0.054 ppmv, respectively, were defined from the current measurements. These values were derived from correlations of $\mathrm{rBC}$ mass versus $\mathrm{CO}_{2}$ and $\mathrm{CO}$, and finding the minimum value of $\mathrm{CO}_{2}$ and $\mathrm{CO}$ on the rBC axis.

All data were collected at $1 \mathrm{~s}$ intervals and are publicly available on the ARM data archive (http://www.archive.arm. gov/armlogin/login.jsp). Unless noted, all data presented are $1 \mathrm{~s}$. Data quality was verified through quality assurance and data quality checks by DOE ARM. CPC, PCASP, OPC, and 
Table 1. Flight identification numbers, start and end times ( $\mathrm{mm} / \mathrm{dd} / \mathrm{yyyy})$ in UTC, flight duration, and waypoints flown over of each G1 research flight during ACME-V. Waypoints O, U, A, I, and T represent Oliktok Point, Utqiagivik, Atqasuk, Ivotuk, and Toolik Lake, respectively. Dates and times are provided as $\mathrm{mm} / \mathrm{dd}$ hh:mm:ss.

\begin{tabular}{|c|c|c|c|c|}
\hline Flight ID & Start (UTC) & End (UTC) & Duration (hh:mm:ss) & Waypoints \\
\hline F01 & 06/04 22:31:21 & 06/05 01:59:40 & $03: 28: 19$ & $\mathrm{O}, \mathrm{U}$ \\
\hline F02 & 06/07 20:08:51 & 06/08 01:16:28 & 05:07:37 & $\mathrm{O}, \mathrm{U}, \mathrm{A}, \mathrm{I}, \mathrm{T}$ \\
\hline F03 & 06/08 19:56:37 & 06/09 00:52:47 & 04:56:10 & $\mathrm{O}, \mathrm{U}, \mathrm{A}, \mathrm{I}, \mathrm{T}$ \\
\hline F04 & 06/10 18:39:18 & 06/10 20:30:59 & 01:51:41 & $\mathrm{O}$ \\
\hline F05 & 06/12 21:58:20 & 06/13 00:11:26 & 02:13:06 & $\mathrm{O}$ \\
\hline F06 & 06/13 18:57:18 & 06/13 23:57:32 & 05:00:14 & $\mathrm{O}, \mathrm{U}, \mathrm{A}, \mathrm{I}, \mathrm{T}$ \\
\hline F07 & 06/15 21:57:26 & 06/16 00:35:49 & $02: 38: 23$ & $\mathrm{O}, \mathrm{U}$ \\
\hline F08 & 06/17 18:59:36 & 06/18 00:11:03 & $05: 11: 27$ & $\mathrm{O}, \mathrm{U}, \mathrm{A}, \mathrm{I}, \mathrm{T}$ \\
\hline F09 & 06/20 19:00:37 & 06/21 00:04:12 & 05:03:35 & $\mathrm{O}, \mathrm{U}, \mathrm{A}, \mathrm{I}, \mathrm{T}$ \\
\hline F10 & 06/22 23:17:43 & 06/23 01:19:26 & 02:01:43 & $\mathrm{O}$ \\
\hline F11 & $06 / 23 \quad 19: 14: 17$ & $06 / 2400: 19: 21$ & 05:05:04 & $\mathrm{O}, \mathrm{U}, \mathrm{A}, \mathrm{I}, \mathrm{T}$ \\
\hline F12 & 06/27 21:06:18 & $06 / 27 \quad 23: 12: 53$ & 02:06:35 & $\mathrm{O}, \mathrm{U}$ \\
\hline F13 & 06/30 18:59:46 & 06/30 22:30:34 & 03:30:48 & $\mathrm{O}, \mathrm{I}, \mathrm{T}$ \\
\hline F14 & 07/02 19:34:03 & 07/02 23:31:36 & 03:57:33 & $\mathrm{O}, \mathrm{U}, \mathrm{T}$ \\
\hline F15 & 07/05 18:57:14 & 07/06 00:10:57 & 05:13:43 & $\mathrm{O}, \mathrm{U}, \mathrm{A}, \mathrm{I}, \mathrm{T}$ \\
\hline F16 & 07/11 20:27:14 & 07/12 00:51:07 & 04:23:53 & $\mathrm{O}, \mathrm{U}, \mathrm{A}, \mathrm{T}$ \\
\hline F17 & 07/14 19:01:15 & 07/14 21:18:25 & $02: 17: 10$ & $\mathrm{O}, \mathrm{T}$ \\
\hline F18 & 07/16 19:58:43 & 07/17 00:38:47 & 04:40:04 & $\mathrm{O}, \mathrm{U}, \mathrm{A}, \mathrm{I}, \mathrm{T}$ \\
\hline F19 & 07/18 19:54:33 & 07/19 00:19:00 & $04: 24: 27$ & $\mathrm{O}, \mathrm{U}, \mathrm{A}, \mathrm{I}, \mathrm{T}$ \\
\hline F20 & 07/21 19:24:37 & 07/22 00:30:44 & 05:06:07 & $\mathrm{O}, \mathrm{U}, \mathrm{A}, \mathrm{I}, \mathrm{T}$ \\
\hline F21 & 07/22 19:29:54 & 07/23 00:14:20 & 04:44:26 & $\mathrm{O}, \mathrm{U}, \mathrm{A}, \mathrm{I}, \mathrm{T}$ \\
\hline F22 & 07/27 21:34:03 & 07/28 00:07:11 & 02:33:08 & $\mathrm{O}, \mathrm{U}$ \\
\hline F23 & 07/30 21:18:11 & 07/31 01:03:48 & 03:45:37 & $\mathrm{O}, \mathrm{U}, \mathrm{A}, \mathrm{T}$ \\
\hline F24 & 08/02 18:10:47 & 08/02 21:40:37 & 03:29:50 & $\mathrm{O}, \mathrm{U}, \mathrm{T}$ \\
\hline F25 & 08/06 19:01:12 & 08/06 23:34:33 & 04:33:21 & $\mathrm{O}, \mathrm{U}, \mathrm{A}, \mathrm{I}, \mathrm{T}$ \\
\hline F26 & 08/07 18:37:02 & 08/07 19:46:35 & 01:09:33 & $\mathrm{O}$ \\
\hline $\mathrm{F} 27$ & 08/08 19:42:22 & 08/08 21:52:35 & 02:10:13 & $\mathrm{O}, \mathrm{U}$ \\
\hline F28 & 08/14 18:49:22 & 08/14 22:17:13 & 03:27:51 & $\mathrm{O}, \mathrm{U}$ \\
\hline F29 & 08/16 19:54:12 & 08/16 23:53:40 & 03:59:28 & $\mathrm{O}$ \\
\hline F30 & 08/20 20:47:02 & 08/21 00:09:46 & 03:22:44 & $\mathrm{O}, \mathrm{U}, \mathrm{A}, \mathrm{I}, \mathrm{T}$ \\
\hline F31 & 08/25 19:18:13 & 08/25 23:52:06 & 04:33:53 & $\mathrm{O}, \mathrm{U}, \mathrm{A}, \mathrm{I}, \mathrm{T}$ \\
\hline F32 & 08/27 21:29:46 & 08/28 01:37:41 & 04:07:55 & $\mathrm{O}, \mathrm{U}, \mathrm{A}, \mathrm{I}, \mathrm{T}$ \\
\hline F33 & 08/28 22:30:14 & $08 / 2900: 51: 35$ & $02: 21: 21$ & $\mathrm{O}$ \\
\hline F34 & 08/30 21:49:18 & 08/30 23:39:16 & 01:49:58 & $\mathrm{O}$ \\
\hline F35 & 09/02 19:00:45 & 09/02 23:27:41 & 04:26:56 & $\mathrm{O}, \mathrm{A}, \mathrm{I}, \mathrm{T}$ \\
\hline F36 & 09/04 21:24:39 & 09/05 00:47:02 & $03: 22: 23$ & $\mathrm{I}, \mathrm{T}$ \\
\hline F37 & 09/07 18:28:10 & 09/07 21:23:57 & $02: 55: 47$ & $\mathrm{O}, \mathrm{A}$ \\
\hline F38 & 09/09 18:29:19 & 09/09 22:18:46 & 03:49:27 & $\mathrm{O}, \mathrm{U}, \mathrm{A}, \mathrm{I}$ \\
\hline
\end{tabular}

rBC data flagged for being in cloud were excluded from the current analysis, since the isokinetic inlet used on the G-1 during the study does not discern between interstitial aerosols and cloud particles, and cloud and aerosol size ranges can potentially overlap. Data periods impacted by liquid and ice clouds were defined as those having $1 \times 10^{7} \mathrm{~m}^{-3}$ droplets and $100 \mathrm{~m}^{-3}$ ice particles larger than $400 \mu \mathrm{m}$, respectively (Lance et al., 2011). When a cloud was found (defined as at least $10 \mathrm{~s}$ of data where the cloud threshold is exceeded), aerosol observations $3 \mathrm{~s}$ before and $3 \mathrm{~s}$ after the cloud were discarded as well to avoid contamination of the aerosol probes with cloud particles (Maahn et al., 2017). CO data were used in and out of cloud since there are no potential artifact issues. To minimize the influence of localized contamination from take-off and landing at the Deadhorse Airport (19.5 m a.m.s.l.), all data below $20 \mathrm{~m}$ a.m.s.l. and within $3 \mathrm{~km}$ of the airport were removed. All data are presented in Coordinated Universal Time (UTC).

\subsection{Supporting satellite data}

The source of aerosols from the central Alaskan fires was determined using imagery from the Moderate Resolution Imaging Spectroradiometer (MODIS) on board the Terra satellite. MODIS Aqua looked similar; thus only Terra observations 


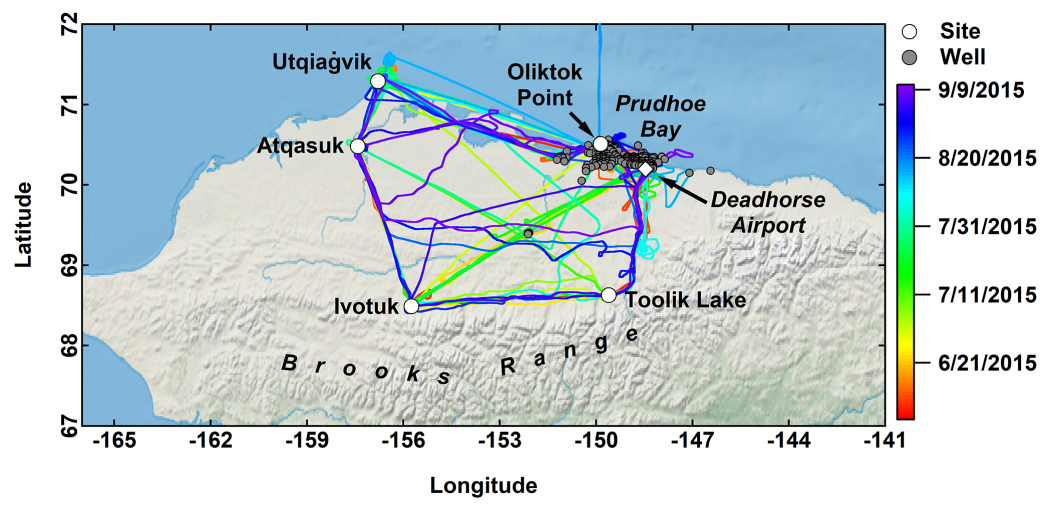

Figure 1. Map of the North Slope of Alaska including flight tracks from the ACME-V field campaign colored by date. Sites where the G-1 aircraft spiralled over are shown (profile waypoint), in addition to locations of actively deployed oil wells (data obtained from http: //doa.alaska.gov/ogc/publicdb.html in March 2017), the location of Deadhorse Airport, and approximate areas of the Brooks Mountain Range and Prudhoe Bay.

are discussed herein. AOD data from MODIS were acquired from the Giovanni data server (http://giovanni.gsfc.nasa.gov/ giovanni/) for daily dark-target deep blue combined mean $\mathrm{AOD}$ at $550 \mathrm{~nm}$ and a $1^{\circ}$ spatial resolution using a domain of 139 to $169^{\circ} \mathrm{W}$ and 57 to $72^{\circ} \mathrm{N}$ (MOD08_D3_6) (Ackerman et al., 1998). Fire and surface thermal anomaly data were also acquired from MODIS using brightness temperature measurements in the 4 and $11 \mu \mathrm{m}$ channels (Giglio, 2010). The fire detection strategy is based on absolute detection of a fire (when the fire strength is sufficient to detect) and on detection relative to its background (to account for variability of the surface temperature and reflection by sunlight) (Giglio et al., 2003). The algorithms include masking of clouds, bright surfaces, glint, and other potential false alarms (Giglio et al., 2003). Swaths from overpasses over the state of Alaska were used to determine the daily locations of fires. The Alaskan fire season was relatively active (i.e., had the highest density of fires) from mid-June to mid-July 2015. Detected thermal anomalies or fires for the 4 June-31 August period are used (thermal anomaly data were not available from 1 to 9 September).

\subsection{Aerosol dispersion modeling}

Aerosol dispersion simulations were executed to demonstrate aerosol transport using version 4 of the Hybrid Single Particle Lagrangian Integrated Trajectory (HYSPLIT4) model (Draxler, 1999; Stein et al., 2015) and $1^{\circ}$ data from the NOAA/National Centers for Environmental Prediction (NCEP) Global Data Assimilation System (GDAS) (Kalnay et al., 1996). Simulation parameterization details are presented by Maahn et al. (2017), but are reiterated briefly here. The HYSPLIT dispersion model simulates emission and subsequent transport of aerosols in forward mode from a point source, enabling qualitative assessment of the spatial extent of dispersion from a source of interest. Aerosol mass concentrations were evaluated qualitatively from one central Prud- hoe Bay location and from five locations within the active fire region in central Alaska at $100 \mathrm{~m}$ intervals from 0 to $5000 \mathrm{~m}$ a.g.l. for $72 \mathrm{~h}$, a $6 \mathrm{~h}$ release of particles at a default emission rate of one arbitrary mass unit for the study time period (1 June-30 September 2015). The five locations were chosen based on equal spacing within the highest density of fires determined from the satellite analyses for the entire study time period. Other input parameters include particle density $\left(6 \mathrm{~g} \mathrm{~cm}^{-3}\right)$; shape factor (1.0); particle diameter $(0.2 \mu \mathrm{m})$ (Eck et al., 1999; Rissler et al., 2006; Brock et al., 2011; Sakamoto et al., 2015); dry deposition velocity $\left(1 \times 10^{-4} \mathrm{~m} \mathrm{~s}^{-1}\right)$ (Warneck, 1999); in-cloud scavenging, defined as a ratio of the pollutant in rain $\left(\mathrm{g} \mathrm{L}^{-1}\right)$ measured at the ground to that in air $\left(\mathrm{g} \mathrm{L}^{-1}\right.$ of air in the cloud layer) $\left(4 \times 10^{4}\right)$; and below-cloud scavenging $\left(5 \times 10^{-6} \mathrm{~s}^{-1}\right)$. Radioactive decay and pollutant resuspension were set to the default values of zero days and $0 \mathrm{~m}^{-1}$, respectively. The results of the dispersion simulations provide arbitrary mass concentrations of particles within the model grid after $72 \mathrm{~h}$ of release from the five fire source locations.

Based on a combination of the HYSPLIT results, thresholds of parameters from previous work, and visual assessment of the proximity to potential sources and vertical profiles, each $1 \mathrm{~s}$ data point was characterized as originating from the Prudhoe Bay oil extraction activities (called Prudhoe Bay herein for brevity), fires, or neither. Remaining data were classified as long-range transport, pristine, or background (see Table 2 for classification parameters and thresholds used). Visual assessments are discussed in more detail throughout Sect. 3. Briefly, Prudhoe Bay emissions were characterized by visual assessment of high concentrations of particles with diameters between 3 and $10 \mathrm{~nm}$ within $50 \mathrm{~km}$ of the Deadhorse Airport. HYSPLIT dispersion results from Deadhorse were used to determine the spatial coverage of Prudhoe Bay emissions. The boundary layer emissions from Prudhoe Bay were restricted to $500 \mathrm{~m}$ a.m.s.l. (Maahn et al., 
Table 2. Classification parameters and thresholds for characterization of $1 \mathrm{~s}$ data as being impacted by one (or more) of the sources shown in Fig. 9b.

\begin{tabular}{|c|c|}
\hline Source & Classification parameter and threshold \\
\hline Prudhoe Bay & $\begin{array}{l}\text { 1. } \mathrm{CPC}_{\text {diff }} \geq 100 \mathrm{~cm}^{-3} \\
\text { 2. Distance from Deadhorse }<50 \mathrm{~km}\end{array}$ \\
\hline Prudhoe Bay boundary layer (BL) & $\begin{array}{l}\text { 1. } \mathrm{CPC}_{\mathrm{diff}} \geq 100 \mathrm{~cm}^{-3} \\
\text { 2. Distance from Deadhorse }<50 \mathrm{~km} \\
\text { 3. Altitude } \leq 500 \mathrm{~m} \text { a.m.s.l. }\end{array}$ \\
\hline All fires & $\begin{array}{l}\text { 1. } \mathrm{rBC} \geq 20 \mathrm{ng} \mathrm{kg}^{-1 \mathrm{a}} \\
\text { 2. } \mathrm{CO} \geq 0.1 \mathrm{ppmv}\end{array}$ \\
\hline Fires south & $\begin{array}{l}\text { 1. } \mathrm{rBC} \geq 20 \mathrm{ng} \mathrm{kg}^{-1} \\
\text { 2. } \mathrm{CO} \geq 0.1 \mathrm{ppmv}^{\circ} \\
\text { 3. Latitude } \leq 69^{\circ} \mathrm{N}\end{array}$ \\
\hline Long-range transport & $\begin{array}{l}\text { 1. No overlapping data with Prudhoe Bay or fires } \\
\text { 2. PCASP } \geq 400 \mathrm{~cm}^{-3 \mathrm{~b}} \\
\text { 3. Altitude } \geq 300 \mathrm{~m} \text { a.m.s.l. }\end{array}$ \\
\hline Pristine & $\begin{array}{l}\text { 1. No overlapping data with Prudhoe Bay, fires, or LRT } \\
\text { 2. PCASP }<400 \mathrm{~cm}^{-3} \\
\text { 3. Distance from Deadhorse }>50 \mathrm{~km}\end{array}$ \\
\hline
\end{tabular}

${ }^{a}$ Maahn et al. (2017). ${ }^{\text {b }}$ Based on threshold value selected from Fig. 8.

2017) and based on changes in vertical profiles of the concentrations of 3-10 nm particles. Fire data were characterized by using thresholds from Maahn et al. (2017). We additionally constrained the data to fires south of $69^{\circ} \mathrm{N}$ to focus closer to the source region (i.e., near the highest density of fires detected by MODIS that overlapped with the flight region). It is important to note that 17 of the $1 \mathrm{~s}$ data points fell under both Prudhoe Bay and fires classifications, but the remaining 496430 data points were characterized under one source. Long-range transport was determined by data that were not characterized as Prudhoe Bay or fires, but had concentrations of $0.1-3 \mu \mathrm{m}$ diameter particles $\geq 400 \mathrm{~cm}^{-1}$ above $300 \mathrm{~m}$ a.m.s.l. based on visual assessment of the vertical profiles. We note that a variety of sources could contribute to this classification, but are likely long-range transported due to the relative concentrations of particles, altitude, and dearth of the other dominant regional sources of aerosol. Pristine conditions were characterized by data that were not classified as from Prudhoe Bay, fires, or long-range transport but had low 0.1-3 $\mu \mathrm{m}$ diameter particle concentrations. Background conditions where characterized as any data remaining after the aforementioned sources were determined.

\section{Results and discussion}

\subsection{Prudhoe Bay is a persistent local source of small particles in the boundary layer}

Figures 2 and 3 show the spatial and vertical variability of select aerosol quantities from ACME-V, respectively. A clear source of aerosol originated from Prudhoe Bay as suggested by the HYSPLIT dispersion model (Fig. 2a) and in situ CN measurements (Fig. 2b and c). The highest number concentrations of 3-10 nm particles (up to $10^{4}$ particles $\mathrm{cm}^{-3}$; calculated from subtracting the CPC 3010 from CPC 3025 number concentrations) and $10 \mathrm{~nm}-3 \mu \mathrm{m}$ sized particles were observed within $50 \mathrm{~km}$ of the Deadhorse Airport (i.e., used here as a proxy for Prudhoe Bay). Particles within the $3-10 \mathrm{~nm}$ size range are associated with nucleated aerosol (i.e., spontaneous in situ aerosol formation from precursor gases) (Colbeck and Lazaridid, 2014). These high number concentrations of small particles are likely formed from gas-to-particle partitioning of reactive gases from flaring and venting along the North Slope. Flaring and venting of gas, which is prominent near the surface in the Arctic near oil and gas facilities (Jaffe et al., 1995; Johnson and Coderre, 2011), could contribute the vapors - such as secondary products from ozone, $\mathrm{SO}_{x}$ and various aromatic hydrocarbons - that induce nucleation of new particles (Wilson and McMurry, 1981; Parungo et al., 1992; Kulmala et al., 2004; Laaksonen et al., 2008; Ismail and Umukoro, 2012; Emam, 2015). Additionally, a sharp decrease in the concentrations of 3-10 nm particles and, to a lesser extent, $10 \mathrm{~nm}-3 \mu \mathrm{m}$ particles was observed 
above $500 \mathrm{~m}$ a.m.s.l. (Fig. 3a and b, respectively), indicating (1) transition of particles via growth into the accumulation mode $(0.1-2.5 \mu \mathrm{m})$ as the plume evolves and disperses vertically (Colbeck and Lazaridid, 2014) or (2) dynamical restriction of these particles in the atmospheric boundary layer. When examining the ratio of the number of 3-10 nm particles to the number of $0.1-3 \mu \mathrm{m}$ particles (i.e., accumulation mode) (Fig. 3c), the ratio was $>1$ (i.e., nucleationmode particles were dominant) for $74 \%$ of the time and $<1$ (i.e., accumulation-mode particles were dominant) for $26 \%$ of the time below $500 \mathrm{~m}$ a.m.s.l. More specifically, the ratio was $>1$ for $86 \%$ of the time when only considering data points classified as Prudhoe Bay. This ratio decreased overall with altitude, indicating the nucleation-mode particles were formed at the lowest altitudes closest to their source, while accumulation-mode particles originated from growth of the nucleation-mode aerosol or a different source (see Sect. 3.3).

Relatively high mass concentrations of $\mathrm{rBC}$ (up to $464 \mathrm{ng} \mathrm{kg}^{-1}$ ) were also observed in the Prudhoe Bay area below $500 \mathrm{~m}$ a.m.s.l. (Figs. 2d and 3d), which likely originated from local combustion sources such as on- and off-road vehicles, facility heating, and to some extent, flaring (Bond et al., 2013; Stohl et al., 2013). Particles measured immediately near oil combustion sources - including $\mathrm{rBC}$ - normally have a size mode around 100-130 nm (Parungo et al., 1992; Chang et al., 2004). The smallest average mass equivalent modal size of the $\mathrm{rBC}$ were 115 and $110 \mathrm{~nm}$ for all data and those closest to Deadhorse, respectively, indicating: (1) particles were "fresher" (i.e., less coated or "aged" from heterogeneous reactions) closest to the Prudhoe Bay source (Maahn et al., 2017) and (2) modal sizes are analogous to what might be expected from oil combustion sources after slight aging due to farther proximity from sources (i.e., not direct measurement from stacks). However, larger sizes and higher mass concentrations (particularly above $500 \mathrm{~m}$ a.m.s.l.) of $\mathrm{rBC}$ were observed further south (Fig. 2d) and were likely influenced by biomass burning emissions as discussed in Sect. 3.2. The localized nature of the smaller-sized $\mathrm{CN}$ and $\mathrm{rBC}$ to the Prudhoe Bay reflect the physical removal processes of the dominant-sized particles occurring from this region. Both nucleation- and Aitken-mode (i.e., 10-100 nm) aerosols have lifetimes on the order of minutes to hours and thus have typical travel distances of one to tens of kilometers (Wilson and Suh, 1997), corroborating our findings of such aerosols within $50 \mathrm{~km}$ of Deadhorse Airport.

Our results demonstrate that Prudhoe Bay is a strong and persistent source of nucleated aerosol and primary combustion aerosol; however, the high mass and number concentrations of these aerosols are restricted to the boundary layer and tend to remain localized to the Prudhoe Bay area. These aerosols may not have strong direct effects on the regional atmospheric radiation budget due to their inherently small size and low concentrations of larger accumulation-mode particles (Friedlander, 2000). This is supported by the fact that no noticeable spatial patterns in absorption and scattering
Below 500 m a.m.s.l.
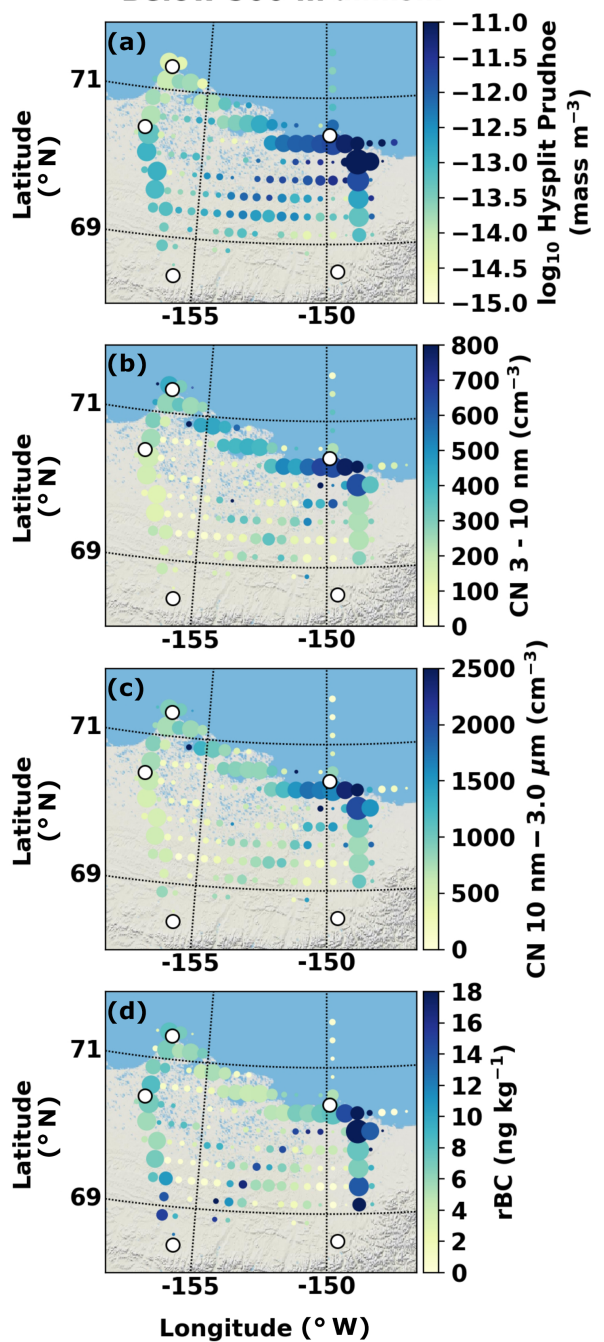

Figure 2. Maps of column average values from 20 to $500 \mathrm{~m}$ a.m.s.1. for (a) HYSPLIT aerosol mass concentrations from Prudhoe Bay, (b) CN with $D_{\mathrm{p}}=3-10 \mathrm{~nm}$, (c) CN with $D_{\mathrm{p}}=10 \mathrm{~nm}-3 \mu \mathrm{m}$, and (d) $\mathrm{rBC}$ mass concentrations. The size of the marker equates to the number of measurements at each $0.25^{\circ}$ latitude $\times 0.50^{\circ}$ longitude grid point. The five white markers show each of the sites where the G-1 spiralled over.

were observed as a function of distance from Deadhorse Airport (not shown). However, as these particles age via atmospheric processing from co-emitted gases such as $\mathrm{SO}_{x} / \mathrm{NO}_{x}$ and grow larger into the accumulation mode, it is possible they could have an impact after sufficient atmospheric residence time downwind. We do not have the compositional data necessary to determine the mixing state or extent of aging of these nucleation-mode particles into the accumulation mode. Additionally, modeling studies have suggested that BC aerosols from Prudhoe Bay oil extraction have a positive net radiative forcing, particularly in summer due to greater absorption of solar radiation (Ødemark et al., 2012). With re- 

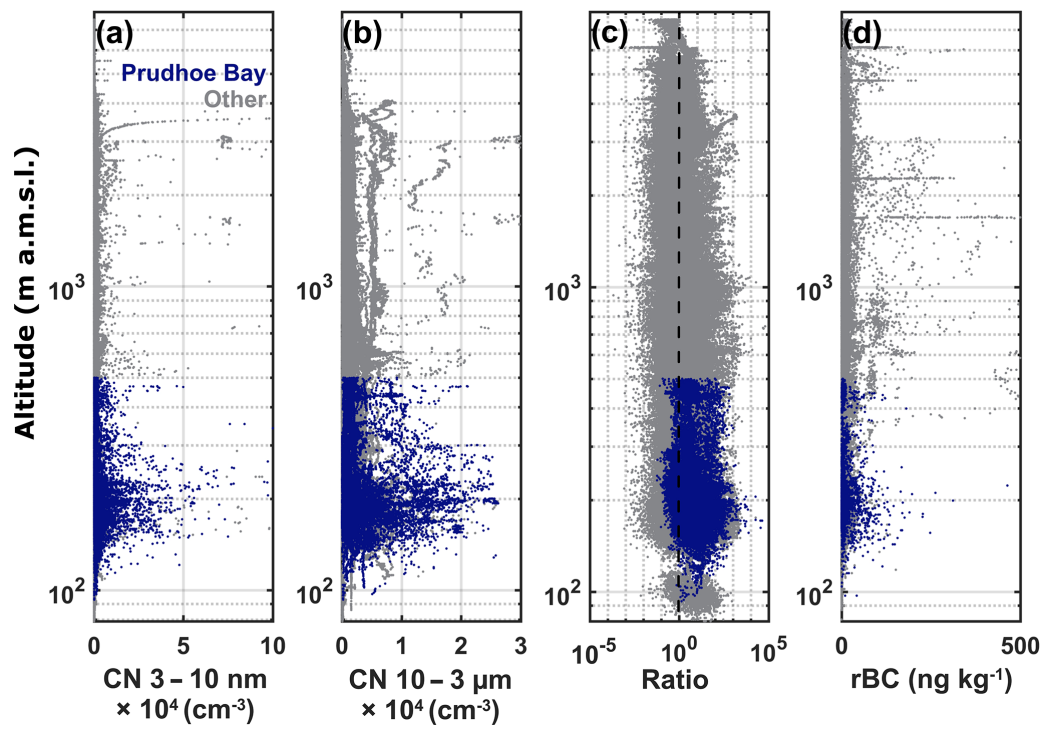

Figure 3. Vertical profiles of CN for (a) $D_{\mathrm{p}}=3-10 \mathrm{~nm}$, (b) $D_{\mathrm{p}}=10 \mathrm{~nm}-3 \mu \mathrm{m}$, (c) the ratio of CN with $D_{\mathrm{p}}=3-10 \mathrm{~nm}$ to CN with $D_{\mathrm{p}}=0.1-$ $3 \mu \mathrm{m}$, and (d) $\mathrm{rBC}$. The dashed line in (c) indicates a ratio of 1 . Note that the $x$ scale for (d) is zoomed in to show the increase below $200 \mathrm{~m}$ a.m.s.l. for rBC (i.e., does not show all rBC data). Data classified as originating from Prudhoe Bay in the boundary layer are colored blue.

gard to indirect effects, Maahn et al. (2017) demonstrated the importance of Prudhoe Bay industrial aerosol in modulation of cloud properties over the North Slope. Further, Leaitch et al. (2016) and Burkart et al. (2017) recently published observations of $\mathrm{CCN}$ diameters down to $20 \mathrm{~nm}$ in the Canadian Arctic; contrary to the conventional wisdom that $100 \mathrm{~nm}$ is the threshold relevant for CCN. However, these Canadian Arctic aerosols were likely compositionally different due to their marine origin and thus could vary in hygroscopicity as compared to oil extraction emissions.

\subsection{Regional fires impact air composition over much of central and northern Alaska}

Another dominant aerosol source observed during the ACME-V field campaign was the central Alaskan wildfires. The 2015 summer fire season was particularly active, leading to the second largest number of acres burned in Alaska since records began in 1940 (Partain Jr. et al., 2016). The highest density of fires detected from satellite lasted from midJune to mid-July (Fig. 4). These fires produced dense plumes of aerosol that propagated over much of the North Slope as evidenced by the high values of AOD originating from the central Alaska wildfires. Flights were impacted by the highAOD regions from late June until the end of July. The G-1 flew directly through the wildfire plumes during 25 June1 July near Toolik Lake (Fig. 4c), 9-15 July over most of the flight track (Fig. 4e), and 16-22 July near Utqiagivik and Oliktok Point (Fig. 4f).

The HYSPLIT dispersion simulations from the five fire source points (Fig. 4, first row) indicate increased particle mass concentrations spread over the flight region, particularly at the southern portion of the domain (Fig. 5a). Analogously, in situ measurements show clear influence of Alaskan boreal fires (Fig. $5 b-d$ ): the number of particles from 0.1 to $3 \mu \mathrm{m}, \mathrm{rBC}$ mass, and $\mathrm{CO}$ were high in concentration, particularly at the southern portion of the flight track close to the Brooks Range. Wildfires emit large quantities of primary organic aerosol (POA) and can generate secondary organic aerosol (SOA) that can develop coatings through aging while transported over long distances (Andreae and Merlet, 2001; Collier et al., 2016; Creamean et al., 2016). Therefore, we would expect to observe an abundance of coarse and accumulation-mode aerosol and a dearth of nucleationmode aerosol, due to the fact that nucleation of new particles is inhibited by precursor vapors instead condensing onto pre-existing aerosol (discussed in more detail in below). The largest impacts from the fires were observed from 400 to 7000 ma.m.s.l. (Fig. 6a). MCE values during measurements impacted by fires were close to 1 (Fig. 6b), indicating active flaming (i.e., "fresher" fires) instead of smouldering. Combined, the HYSPLIT and MCE data suggest fires were recent, yet emissions from the fires were ejected high into the troposphere. $\mathrm{CO}$ and $\mathrm{rBC}$ concentrations were strongly correlated $\left(r^{2}=0.83\right)$ and reached $0.626 \mathrm{ppmv}$ and $1490 \mathrm{ng} \mathrm{kg}^{-1}$, respectively (Fig. 6c). CO is a poor tracer for oil extraction since it originates from combustion; thus, aside from the operational vehicles in Prudhoe Bay, we would expect the boreal fires to most strongly influence CO during the campaign (Crutzen et al., 1979; Andreae and Merlet, 2001). Background CO concentrations have been measured at $0.120 \mathrm{ppmv}$ using summertime surface measurements at 

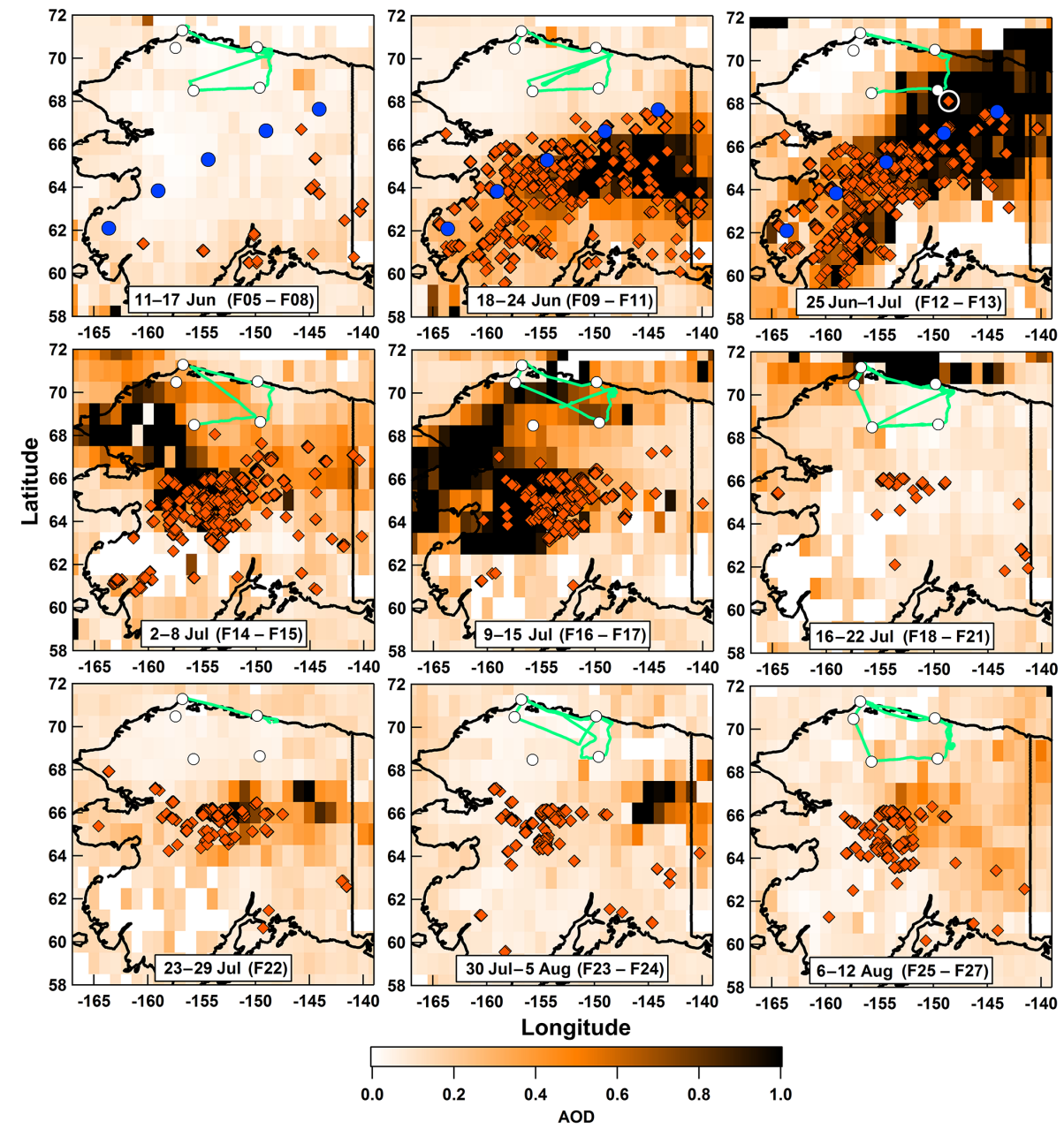

Figure 4. Maps of AOD and fires (i.e., thermal anomalies; orange diamonds) detected by MODIS for the 11 June-12 August time period, showing the transition from few fires to the highest density of fires and back. Flight tracks (green lines) and site locations (white circles) are also shown during each corresponding time period. The blue markers in the top left panel signify HYSPLIT fire start point locations. The white circle in the top right panel denotes the fire closest to Toolik Lake on 30 June.

Utqiagivik and up to 0.4 ppmv during ARCPAC airborne measurements of springtime long-range-transported biomass burning plumes (Liang et al., 2004; Brock et al., 2011). Brock et al. (2011) reported springtime $\mathrm{rBC}$ mass concentrations of up to $1000 \mathrm{ng} \mathrm{m}^{-3}$ using the SP2 instrument also used in the current study. Although the fires were an abundant source of absorbing $\mathrm{rBC}$, highly scattering aerosol originated from the fires (Fig. 6d), which could be explained by previous work indicating fires produce larger quantities of organic carbon and sulfate (Penner et al., 1992; Wiedinmyer et al., 2011). Our observations are parallel to previous summertime observations from regional boreal fires in that such fires produce substantial quantities of aerosol (Stohl et al., 2006; Eck et al., 2009), which is likely due to the proximity of the measurements to the source.

Notably, anomalously high rBC mass and CO concentrations were measured during a few flights (F13, F17, and F18). Almost all measurements from F13 (30 June flight) were considerably high - including $\mathrm{CO}$ (maximum of $0.626 \mathrm{ppmv})$, rBC (1490 $\left.\mathrm{ng} \mathrm{kg}^{-1}\right)$, aerosol number concentrations $\left(20596 \mathrm{~cm}^{-3}\right.$ for CPC $3010,11021 \mathrm{~cm}^{-3}$ for PCASP, and $30 \mathrm{~cm}^{-3}$ for OPC), absorption $\left(61.1 \mathrm{Mm}^{-1}\right)$, and scattering $\left(978.1 \mathrm{Mm}^{-1}\right)$ - as compared to other flights impacted by the fires (Fig. 7). AOD was relatively high (>0.1) and a fire was detected by MODIS close to Toolik Lake (see Fig. 4c) on 30 June, which is likely why the measurements were highest when spiralling over the waypoint and then decreased as the aircraft flew low to/from adjacent waypoints. However, the plume on 30 June also reached higher altitudes above Oliktok Point (as supported by MODIS), indicating the biomass burning plume ascended as it propagated northward. The only exception to the considerably high nature of the aerosol concentrations is nucleation-mode aerosol, which was only slightly elevated 
Below 500 m a.m.s.I.
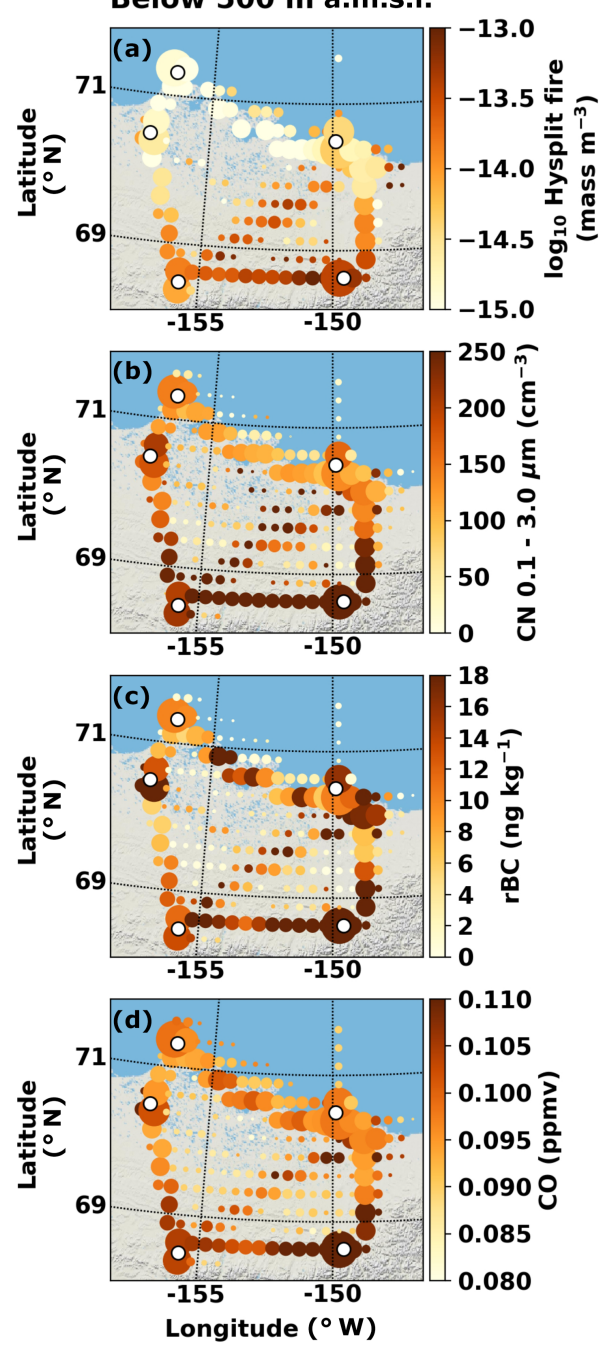

Figure 5. Same as Fig. 2, but column-averaged from 20 to $5000 \mathrm{~m}$ a.m.s.l. and for (a) HYSPLIT aerosol mass concentrations with the five fire locations as the simulation start points, (b) $\mathrm{CN}$ with $D_{\mathrm{p}}=0.1-3 \mu \mathrm{m},(\mathbf{c}) \mathrm{rBC}$ mass, and (d) CO.

in concentration (maximum of $2500 \mathrm{~cm}^{-3}$ as compared to a maximum of $101940 \mathrm{~cm}^{-3}$ for the same-sized particles from Prudhoe Bay) and was not elevated over Oliktok Point, demonstrating the short lifetimes of these small-sized particles (via growth into the accumulation mode) in densely populated biomass burning plumes.

The large quantity of aerosol observed from the lowest to highest altitudes flown by the aircraft closest to the Brooks Range indicate the thickness of the biomass burning aerosol layer. These particles can have implications for both the local energy budget and cloud formation. We observed how aerosols from the 30 June fire event were highly absorbing and scattering relative to the rest of the region (Fig. 7e and $\mathrm{f}$, respectively). Both organic and inorganic components of aerosols from wildfires can be highly hygroscopic and serve
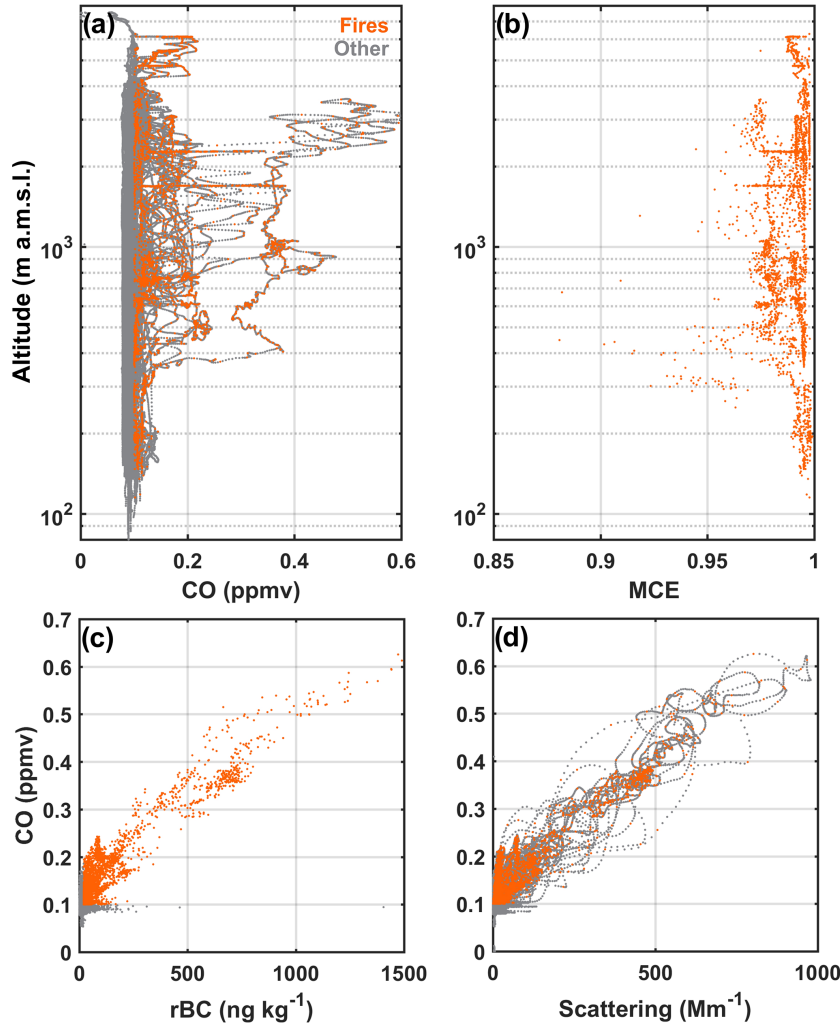

Figure 6. Vertical profiles of (a) $\mathrm{CO}$ and (b) calculated modified combustion efficiency (MCE). MCE is only calculated for fire data. Correlations between $\mathrm{CO}$ and (c) rBC mass and (d) scattering coefficients at $550 \mathrm{~nm}$ for all data are also shown. Data classified as originating from the fires are colored orange.

as efficient CCN (Novakov and Corrigan, 1996; Petters et al., 2009a; Engelhart et al., 2012), while mineral dust, carbonaceous, and biological aerosols from wildfires have been shown to increase atmospheric INP concentrations (Petters et al., 2009b; McCluskey et al., 2014). Additionally, ejection of such a large quantity of aerosol and trace gases into the atmosphere can affect air quality on the North Slope and to the Arctic beyond over the course of a couple of weeks (Stohl et al., 2013).

\subsection{Relative contributions from regional and long-range-transported sources of aerosol to North Slope}

Weaker poleward advection and strong aerosol removal via wet deposition make the Arctic less subject to transport from mid-latitude sources during summer as compared to the spring Arctic haze season (Polissar et al., 2001; Eckhardt et al., 2003; Garrett et al., 2010; Browse et al., 2012; Bian et al., 2013). During summer, aerosol production from local natural sources - from terrestrial and marine microbial processes and mechanical generation of sea salt - is dominant at the ground and aloft (Gregory et al., 1992; Quinn et al., 2002; 

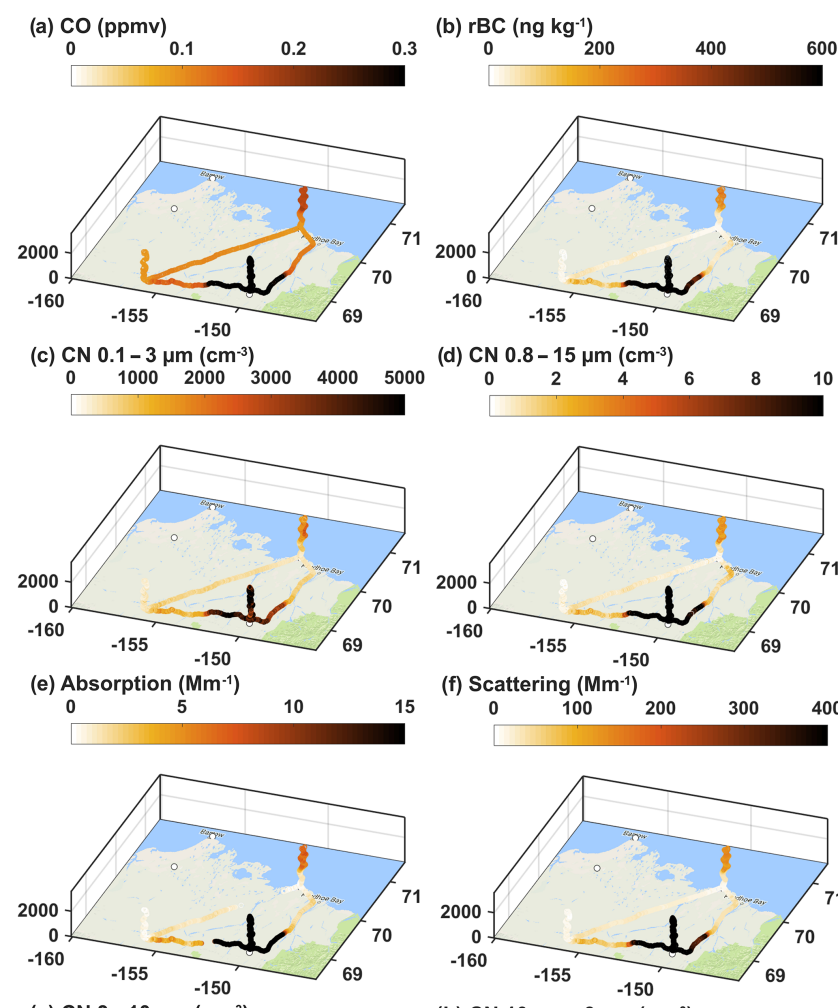

(g) $\mathrm{CN} 3-10 \mathrm{~nm}\left(\mathrm{~cm}^{-3}\right)$
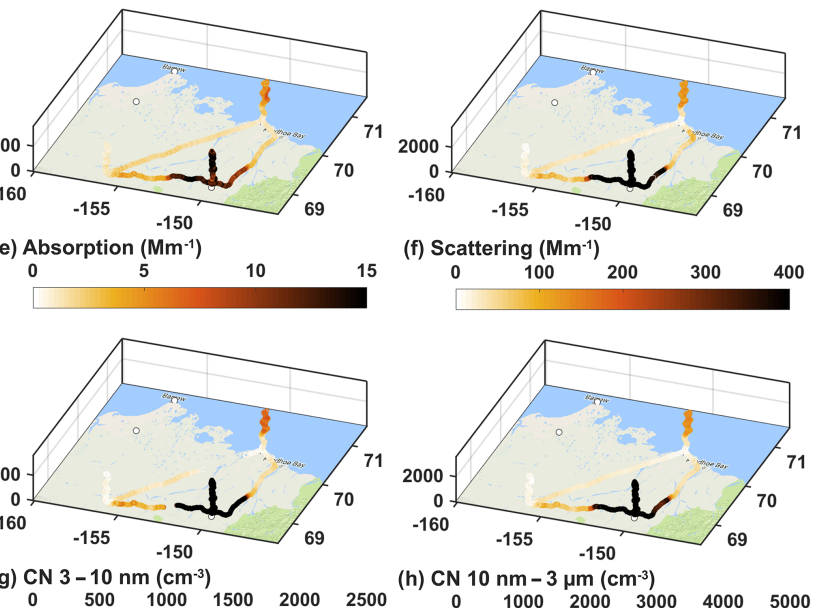

(h) $\mathrm{CN} 10 \mathrm{~nm}-3 \mu \mathrm{m}\left(\mathrm{cm}^{-3}\right)$
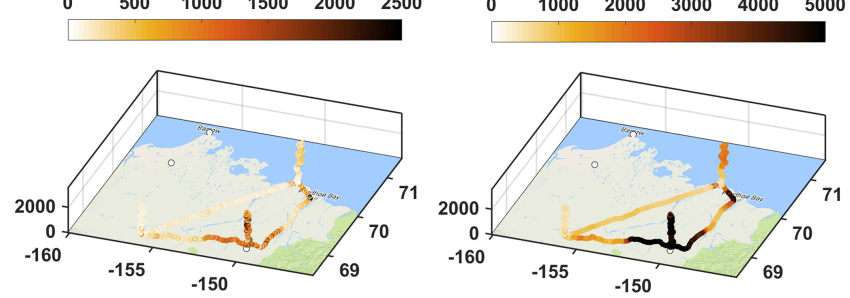

Figure 7. 4-D profiles of (a) $\mathrm{CO}$, (b) $\mathrm{rBC}$ mass, (c) $\mathrm{CN}$ with $D_{\mathrm{p}}=$ $0.1-3 \mu \mathrm{m}$, (d) CN with $D_{\mathrm{p}}=0.8-15 \mu \mathrm{m}$, (e) absorption coefficient, (f) scattering coefficient, (g) $\mathrm{CN}$ with $D_{\mathrm{p}}=3-10 \mathrm{~nm}$, and (h) $\mathrm{CN}$ with $D_{\mathrm{p}}=10 \mathrm{~nm}-3 \mu \mathrm{m}$ from F13 on 30 June. The left, bottom, and right axes are altitude, longitude, and latitude, respectively.

Leaitch et al., 2013, 2016; Burkart et al., 2017). Although the concentrations of pollutants from mid-latitudes is typically lower during summer (Raatz and Shaw, 1984), we observed occasional episodic increases in accumulation- and coarsemode aerosol measured by the PCASP and OPC at higher altitudes (Fig. 8), without the presence of Prudhoe Bay or Alaskan fire tracers of $\mathrm{CO}$ and $\mathrm{rBC}$. These layers were deficient in $\mathrm{CO}, \mathrm{rBC}$, and $3-10 \mathrm{~nm}$ particles, and were present during flights where biomass burning was not detected as a dominant source. Thus, we assume these events were not a result of local or regional emissions that dominated the North Slope aerosol. These diagnosed long-range transport events were only observed during flights $1,9,10$, and 11 , thus supporting the idea that poleward advection is less frequent and
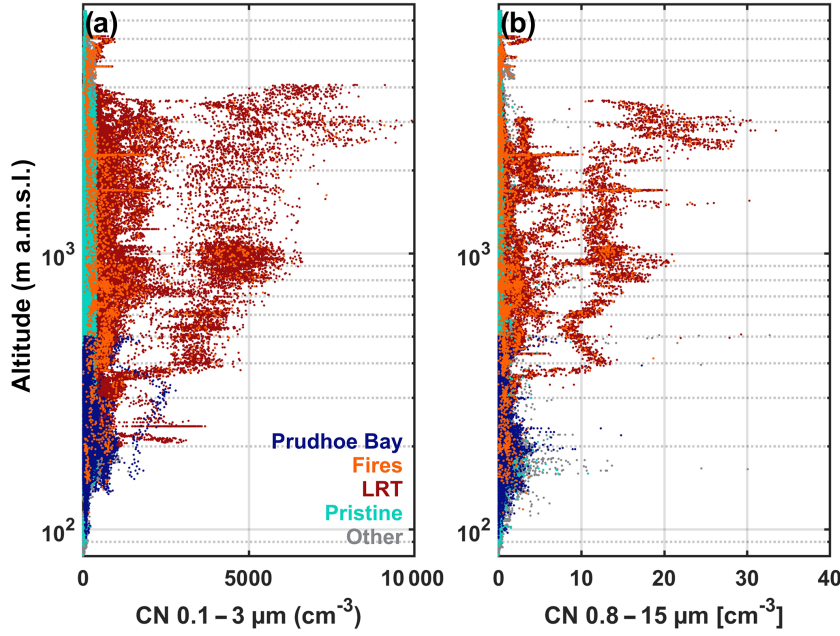

Figure 8. Vertical profiles of (a) $\mathrm{CN}$ with $D_{\mathrm{p}}=0.1-3 \mu \mathrm{m}$ and (b) $\mathrm{CN}$ with $D_{\mathrm{p}}=0.8-15 \mu \mathrm{m}$. Data classified as originating from Prudhoe Bay in the boundary layer, fires, and long-range transported are colored blue, orange, and red, respectively.

wet removal processes are enhanced in summer as compared to the Arctic haze season.

Recent studies have alluded to the possibility that the Arctic summer may not be as pristine as previously thought (Stohl et al., 2013). Modeled emissions from ARCTAS-A highlight summertime boreal fires and their impact on Arctic pollution; however, these flights targeted local fire plumes and were limited to the Canadian Arctic. Further, Bian et al. (2013) state that the ARCTAS-A measurements "cannot provide a comprehensive and representative picture of Arctic pollution in the summer". We evaluated all ACME-V data and classified each flight as impacted by fires, Prudhoe Bay, long-range transport, or some combination of these (Fig. 9a). All flights contained at least a small segment that was classified as background, but flights where only background conditions were observed are labeled as such. Due to the aircraft being based in Deadhorse, emissions from Prudhoe Bay impacted nearly every flight (31 flights; remaining 7 flights were flagged for clouds near Prudhoe Bay; thus those data were eliminated from the analysis), while regional fires impacted 22 flights, and long-range transport impacted only 4 flights. For a more statistical representation of the sources, we classified each $1 \mathrm{~s}$ data point as influenced from fires at all flight locations, fires from the lowest latitude flown to $69^{\circ} \mathrm{N}$ (i.e., a subset of all fires), Prudhoe Bay emissions strictly near Prudhoe Bay, emissions near Prudhoe Bay in the boundary layer, long-range transport, background, and pristine conditions (Fig. 9b; see Table 2 for classification definitions). Background may include aerosol from Prudhoe Bay or the fires after significant atmospheric residence time, but we cannot distinguish these from local natural aerosol emission or production that is traditionally observed with the measurements obtained. This plot demonstrates the episodic behavior 

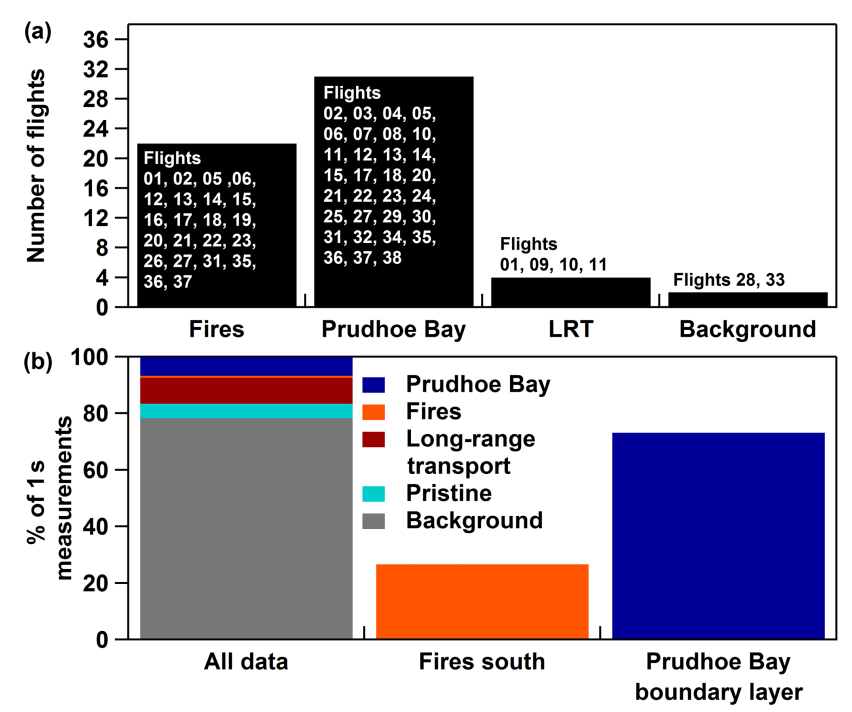

Figure 9. (a) The number of flights that were classified as impacted by aerosols from the central Alaskan fires, Prudhoe Bay, long-range transport, pristine conditions, and background (based on parameter thresholds in Table 2). (b) Percentage of measurements that were impacted by fires, Prudhoe Bay, long-range transport, pristine conditions, and background. Fires south of $69^{\circ} \mathrm{N}$ are shown by the second bar from the left (percentage was calculated out of number of fire data points in b). The percentage of Prudhoe Bay data points (i.e., from the blue portion in the first bar in $\mathbf{b}$ ); data in the boundary layer are shown by the last bar from the left.

of the fires and the localized behavior of Prudhoe Bay emissions. However, what we are calling "pristine" conditions had the lowest occurrence overall (only $5 \%$ ), which contrasts with previous North Slope summertime aerosol studies. It is important to note that these data are dependent on the location and height of the aircraft, thus may be biased. However, it provides a general overview of the sources of aerosols in the context of the flight locations but may not be representative of the entire North Slope at all times.

\section{Summary}

Results from the 2015 airborne ARM ACME-V field campaign demonstrate that the summer in the Alaskan Arctic is not necessarily characterized by clean conditions. The pristine nature of the atmosphere was dependent on the influence from episodic wildfires, localized oil extraction activities, and, to a lesser extent, long-range-transport. Probably the most notable observation was that Prudhoe Bay is a persistent but localized source of rBC and especially nucleated aerosol, supporting previous findings at Utqiagivik from Kolesar et al. (2017) and Gunsch et al. (2017), but demonstrating the larger influence of particle nucleation on the aerosol population in the vicinity surrounding Prudhoe Bay. Such elevated aerosol levels have been shown to alter the microphysics of clouds in this region (Maahn et al., 2017), potentially impacting their radiative forcing on the surface. Most previous measurements along the North Slope have been conducted at the ground at a single location, thus thwarting the evaluation of the spatiotemporal heterogeneity of aerosol in the entire Alaskan Arctic. Although our results reveal that these sources are not significant on a larger scale (i.e., the entire North Slope), they yield valuable information on local and regional Arctic pollution sources, which produce substantial quantities of aerosols that may be transported downstream and beyond. Further, although our observations are limited to the location and dynamical conditions of the North Slope, they can serve as a proxy for other parts of the Arctic subject to oil exploration or boreal fires. With both fire activity and oil exploration projected to increase in a warming climate, these sources will likely continue to make significant contributions to the aerosol population of the Arctic atmosphere. The particles emitted from these sources can impact atmospheric radiative transfer through modulation of cloud microphysics and direct radiative forcing. To fully understand the impacts of these particles and their relative frequency of occurrence, additional observational, modeling, and theoretical studies are required.

Data availability. Data are publicly available at the DOE ARM data archive portal (http://www.archive.arm.gov/armlogin/login. jsp).

Author contributions. JMC analyzed and interpreted ARM ACMEV aerosol data, MODIS AOD and thermal anomaly data; ran HYSPLIT simulations; and wrote the manuscript. MM participated in ACME-V aerosol and HYSPLIT data analyses and handled oil well data. GdB and AM helped with general interpretation of the ACME$\mathrm{V}$ data. AJS and YF helped with MCE calculations and interpretation of the SP2 measurements. All co-authors contributed to the writing of or provided comments for the manuscript.

Competing interests. The authors declare that they have no conflict of interest.

Acknowledgements. This analysis was supported by funding from the US Department of Energy's Office of Science under the Atmospheric System Research (ASR) program (grant DESC0013306). We would like to acknowledge those involved with execution of the ARM ACME-V field campaign, including Sebastien Biraud, Margaret Torn, Duli Chand, Connor Flynn, John Hubbe, Fan Mei, Mikhail Pekour, Stephen Springston, and Jason Tomlinson. Additionally, we gratefully acknowledge the NOAA Air Resources Laboratory (ARL) for the provision of the HYSPLIT transport and dispersion model and READY website (http://www.ready.noaa.gov) used in this publication. Lastly, we acknowledge the use of data and imagery from Land, Atmosphere Near real-time Capability for EOS Land, Atmosphere Near 
real-time Capability for EOS (LANCE FIRMS) operated by the NASA/GSFC/Earth Science Data and Information System (ESDIS) with funding provided by NASA/HQ.

Edited by: Anja Schmidt

Reviewed by: three anonymous referees

\section{References}

Ackerman, S. A., Strabala, K. I., Menzel, W. P., Frey, R. A., Moeller, C. C., and Gumley, L. E.: Discriminating clear sky from clouds with MODIS, J. Geophys. Res.-Atmos., 103, 3214132157, 1998.

Andreae, M. O. and Merlet, P.: Emission of trace gases and aerosols from biomass burning, Global Biogeochem. Cy., 15, 955-966, 2001.

Arnold, S., Law, K. S., Brock, C. A., Thomas, J. L., Starkweather, S. M., Salzen, K. v., Stohl, A., Sharma, S., Lund, M. T., Flanner, M. G., Petäjä, T., Tanimoto, H., Gamble, J., Dibb, J. E., Melamed, M., Johnson, N., Fidel, M., Tynkkynen, V.-P., Baklanov, A., Eckhardt, S., Monks, S. A., Browse, J., and Bozem, H.: Arctic air pollution: Challenges and opportunities for the next decade, Elem. Sci. Anth., 104, https://doi.org/10.12952/journal.elementa.000104, 2016.

Barrie, L. A.: Arctic air pollution: An overview of current knowledge, Atmos. Environ., 20, 643-663, 1986.

Bian, H., Colarco, P. R., Chin, M., Chen, G., Rodriguez, J. M., Liang, Q., Blake, D., Chu, D. A., da Silva, A., Darmenov, A. S., Diskin, G., Fuelberg, H. E., Huey, G., Kondo, Y., Nielsen, J. E., Pan, X., and Wisthaler, A.: Source attributions of pollution to the Western Arctic during the NASA ARCTAS field campaign, Atmos. Chem. Phys., 13, 4707-4721, https://doi.org/10.5194/acp13-4707-2013, 2013.

Biraud, S. and Reichl, K.: Aerosol Observing System Greenhouse Gas (AOS GHG) Monitor Handbook U.S. Department of Energy, Office of Science, Office of Biological and Environmental Research, Washington, D.C., 2016.

Biraud, S., Mei, F., Flynn, C., Hubbe, J., Long, C., Matthews, A., Pekour, M., Sedlacek, A., Springston, S., Tomlinson, J., and Chand, D.: Campaign datasets for ARM Airborne Carbon Measurements (ARM-ACME-V), https://doi.org/10.5439/1346549, 2016.

Bond, T. C., Doherty, S. J., Fahey, D. W., Forster, P. M., Berntsen, T., DeAngelo, B. J., Flanner, M. G., Ghan, S., Karcher, B., Koch, D., Kinne, S., Kondo, Y., Quinn, P. K., Sarofim, M. C., Schultz, M. G., Schulz, M., Venkataraman, C., Zhang, H., Zhang, S., Bellouin, N., Guttikunda, S. K., Hopke, P. K., Jacobson, M. Z., Kaiser, J. W., Klimont, Z., Lohmann, U., Schwarz, J. P., Shindell, D., Storelvmo, T., Warren, S. G., and Zender, C. S.: Bounding the role of black carbon in the climate system: A scientific assessment, J. Geophys. Res.-Atmos., 118, 5380-5552, 2013.

Boucher, O., Randall, D., Artaxo, P., Bretherton, C., Feingold, G., Forster, P., Kerminen, V. M., Kondo, Y., Liao, H., Lohmann, U., Rasch, P., Satheesh, S. K., Sherwood, S., Stevens, B., and Zhang, X. Y.: Clouds and Aerosols, in: Climate Change 2013: The Physical Science Basis. Contribution of Working Group I to the Fifth Assessment Report of the Intergovernmental Panel on Climate Change, edited by: Stocker, T. F., Qin, D., Plattner, G.-K., Tig- nor, M., Allen, S. K., Boschung, J., Nauels, A., Xia, Y., Bex, V., and Midgley, P. M., Cambridge University Press, Cambridge, UK and New York, NY, USA, 571-658, 2013.

Brock, C. A., Cozic, J., Bahreini, R., Froyd, K. D., Middlebrook, A. M., McComiskey, A., Brioude, J., Cooper, O. R., Stohl, A., Aikin, K. C., de Gouw, J. A., Fahey, D. W., Ferrare, R. A., Gao, R. S., Gore, W., Holloway, J. S., Hübler, G., Jefferson, A., Lack, D. A., Lance, S., Moore, R. H., Murphy, D. M., Nenes, A., Novelli, P. C., Nowak, J. B., Ogren, J. A., Peischl, J., Pierce, R. B., Pilewskie, P., Quinn, P. K., Ryerson, T. B., Schmidt, K. S., Schwarz, J. P., Sodemann, H., Spackman, J. R., Stark, H., Thomson, D. S., Thornberry, T., Veres, P., Watts, L. A., Warneke, C., and Wollny, A. G.: Characteristics, sources, and transport of aerosols measured in spring 2008 during the aerosol, radiation, and cloud processes affecting Arctic Climate (ARCPAC) Project, Atmos. Chem. Phys., 11, 2423-2453, 2011.

Browse, J., Carslaw, K. S., Arnold, S. R., Pringle, K., and Boucher, O.: The scavenging processes controlling the seasonal cycle in Arctic sulphate and black carbon aerosol, Atmos. Chem. Phys., 12, 6775-6798, 2012.

Burkart, J., Willis, M. D., Bozem, H., Thomas, J. L., Law, K., Hoor, P., Aliabadi, A. A., Köllner, F., Schneider, J., Herber, A., Abbatt, J. P. D., and Leaitch, W. R.: Summertime observations of elevated levels of ultrafine particles in the high Arctic marine boundary layer, Atmos. Chem. Phys., 17, 5515-5535, https://doi.org/10.5194/acp-17-5515-2017, 2017.

Chang, M. C. O., Chow, J. C., Watson, J. G., Hopke, P. K., Yi, S.M., and England, G. C.: Measurement of Ultrafine Particle Size Distributions from Coal-, Oil-, and Gas-Fired Stationary Combustion Sources, J. Air Waste Manage., 54, 1494-1505, 2004.

Chapin, F. S., Sturm, M., Serreze, M. C., McFadden, J. P., Key, J. R., Lloyd, A. H., McGuire, A. D., Rupp, T. S., Lynch, A. H., Schimel, J. P., Beringer, J., Chapman, W. L., Epstein, H. E., Euskirchen, E. S., Hinzman, L. D., Jia, G., Ping, C.-L., Tape, K. D., Thompson, C. D. C., Walker, D. A., and Welker, J. M.: Role of Land-Surface Changes in Arctic Summer Warming, Science, 310, 657-660, 2005.

Colbeck, I. and Lazaridid, M.: Aerosol Science Technology and Applications, John Wiley \& Sons Ltd, 2014.

Collier, S., Zhou, S., Onasch, T. B., Jaffe, D. A., Kleinman, L., Sedlacek, A. J., Briggs, N. L., Hee, J., Fortner, E., Shilling, J. E., Worsnop, D., Yokelson, R. J., Parworth, C., Ge, X., Xu, J., Butterfield, Z., Chand, D., Dubey, M. K., Pekour, M. S., Springston, S., and Zhang, Q.: Regional Influence of Aerosol Emissions from Wildfires Driven by Combustion Efficiency: Insights from the BBOP Campaign, Environ. Sci. Technol., 50, 8613-8622, 2016.

Creamean, J. M., Neiman, P. J., Coleman, T., Senff, C. J., Kirgis, G., Alvarez, R. J., and Yamamoto, A.: Colorado air quality impacted by long-range-transported aerosol: a set of case studies during the 2015 Pacific Northwest fires, Atmos. Chem. Phys., 16, 1232912345, https://doi.org/10.5194/acp-16-12329-2016, 2016.

Crutzen, P. J., Heidt, L. E., Krasnec, J. P., Pollock, W. H., and Seiler, W.: Biomass burning as a source of atmospheric gases $\mathrm{CO}, \mathrm{H}_{2}$, $\mathrm{N}_{2} \mathrm{O}, \mathrm{NO}, \mathrm{CH}_{3} \mathrm{Cl}$ and COS, Nature, 282, 253-256, 1979.

de Groot, W. J., Flannigan, M. D., and Cantin, A. S.: Climate change impacts on future boreal fire regimes, Forest Ecol. Manage., 294, 35-44, 2013. 
Delene, D. J. and Ogren, J. A.: Variability of Aerosol Optical Properties at Four North American Surface Monitoring Sites, J. Atmos. Sci., 59, 1135-1150, 2002.

Draxler, R. R.: HYSPLIT4 user's guide, NOAA Tech. Memo. ERL ARL-230, NOAA Air Resources Laboratory, Silver Spring, MD, 1999.

Eck, T. F., Holben, B. N., Reid, J. S., Dubovik, O., Smirnov, A., O'Neill, N. T., Slutsker, I., and Kinne, S.: Wavelength dependence of the optical depth of biomass burning, urban, and desert dust aerosols, J. Geophys. Res.-Atmos., 104, 3133331349, 1999.

Eck, T. F., Holben, B. N., Reid, J. S., Sinyuk, A., Hyer, E. J., O’Neill, N. T., Shaw, G. E., Castle, J. R. V., Chapin, F. S., Dubovik, O., Smirnov, A., Vermote, E., Schafer, J. S., Giles, D., Slutsker, I., Sorokine, M., and Newcomb, W. W.: Optical properties of boreal region biomass burning aerosols in central Alaska and seasonal variation of aerosol optical depth at an Arctic coastal site, J. Geophys. Res.-Atmos., 114, D11201, https://doi.org/10.1029/2008JD010870, 2009.

Eckhardt, S., Stohl, A., Beirle, S., Spichtinger, N., James, P., Forster, C., Junker, C., Wagner, T., Platt, U., and Jennings, S. G.: The North Atlantic Oscillation controls air pollution transport to the Arctic, Atmos. Chem. Phys., 3, 1769-1778, https://doi.org/10.5194/acp-3-1769-2003, 2003.

Emam, E. A.: Gas flaring in industry: An overview, Petroleum \& Coal, 57, 532-555, 2015.

Engelhart, G. J., Hennigan, C. J., Miracolo, M. A., Robinson, A. L., and Pandis, S. N.: Cloud condensation nuclei activity of fresh primary and aged biomass burning aerosol, Atmos. Chem. Phys., 12, 7285-7293, https://doi.org/10.5194/acp12-7285-2012, 2012.

Friedlander, S. K.: From Smoke, Dust, and Haze: Fundamentals of Aerosol Dynamics, 2nd Edn., Oxford University Press, Inc., New York, New York, 2000.

Garrett, T. J., Zhao, C., and Novelli, P. C.: Assessing the relative contributions of transport efficiency and scavenging to seasonal variability in Arctic aerosol, Tellus B, 62, 190-196, 2010.

Gautier, D. L., Bird, K. J., Charpentier, R. R., Grantz, A., Houseknecht, D. W., Klett, T. R., Moore, T. E., Pitman, J. K., Schenk, C. J., Schuenemeyer, J. H., Sørensen, K., Tennyson, M. E., Valin, Z. C., and Wandrey, C. J.: Assessment of Undiscovered Oil and Gas in the Arctic, Science, 324, 1175-1179, 2009.

Giglio, L.: MODIS Collection 5 Active Fire Product User's Guide Version 2.4, Science Systems and Applications, Inc., 2010.

Giglio, L., Descloitres, J., Justice, C. O., and Kaufman, Y. J.: An enhanced contextual fire detection algorithm for MODIS, Remote Sens. Environ., 87, 273-282, 2003.

Graversen, R. G., Mauritsen, T., Tjernstrom, M., Kallen, E., and Svensson, G.: Vertical structure of recent Arctic warming, Nature, 451, 53-56, 2008.

Gregory, G. L., Anderson, B. E., Warren, L. S., Browell, E. V., Bagwell, D. R., and Hudgins, C. H.: Tropospheric Ozone and Aerosol Observations - the Alaskan Arctic, J. Geophys. Res.Atmos., 97, 16451-16471, 1992.

Gunsch, M. J., Kirpes, R. M., Kolesar, K. R., Barrett, T. E., China, S., Sheesley, R. J., Laskin, A., Wiedensohler, A., Tuch, T., and Pratt, K. A.: Contributions of transported Prudhoe Bay oil field emissions to the aerosol population in Utqiagvik, Alaska, Atmos.
Chem. Phys., 17, 10879-10892, https://doi.org/10.5194/acp-1710879-2017, 2017.

Harsem, Ø., Eide, A., and Heen, K.: Factors influencing future oil and gas prospects in the Arctic, Energ. Policy, 39, 8037-8045, 2011.

Heintzenberg, J., Leck, C., and Tunved, P.: Potential source regions and processes of aerosol in the summer Arctic, Atmos. Chem. Phys., 15, 6487-6502, https://doi.org/10.5194/acp-156487-2015, 2015.

Hobbs, P. V. and Rangno, A. L.: Microstructures of low and middlelevel clouds over the Beaufort Sea, Q. J. Roy. Meteor. Soc., 124, 2035-2071, 1998.

Ismail, O. S. and Umukoro, G. E.: Global Impact of Gas Flaring, Energy and Power Engineering, 4, 20231, https://doi.org/10.4236/epe.2012.44039, 2012.

Jackson, R. C., McFarquhar, G. M., Korolev, A. V., Earle, M. E., Liu, P. S. K., Lawson, R. P., Brooks, S., Wolde, M., Laskin, A., and Freer, M.: The dependence of ice microphysics on aerosol concentration in arctic mixed-phase stratus clouds during ISDAC and M-PACE, J. Geophys. Res.-Atmos., 117, D15207, https://doi.org/10.1029/2012JD017668, 2012.

Jaffe, D. A., Honrath, R. E., Furness, D., Conway, T. J., Dlugokencky, E., and Steele, L. P.: A determination of the $\mathrm{CH}_{4}, \mathrm{NO}_{x}$ and $\mathrm{CO}_{2}$ emissions from the Prudhoe Bay, Alaska oil development, J. Atmos. Chem., 20, 213-227, 1995.

Jeffries, M. O., Overland, J. E., and Perovich, D. K.: The Arctic shifts to a new normal, Phys. Today, 66, 35-40, 2013.

Johnson, M. R. and Coderre, A. R.: An Analysis of Flaring and Venting Activity in the Alberta Upstream Oil and Gas Industry, J. Air Waste Manage., 61, 190-200, 2011.

Kalnay, E., Kanamitsu, M., Kistler, R., Collins, W., Deaven, D., Gandin, L., Iredell, M., Saha, S., White, G., Woollen, J., Zhu, Y., Leetmaa, A., Reynolds, R., Chelliah, M., Ebisuzaki, W., Higgins, W., Janowiak, J., Mo, K. C., Ropelewski, C., Wang, J., Jenne, R., and Joseph, D.: The NCEP/NCAR 40-Year Reanalysis Project, B. Am. Meteorol. Soc., 77, 437-471, 1996.

Kassianov, E., Berg, L. K., Pekour, M., Barnard, J., Chand, D., Flynn, C., Ovchinnikov, M., Sedlacek, A., Schmid, B., Shilling, J., Tomlinson, J., and Fast, J.: Airborne Aerosol in Situ Measurements during TCAP: A Closure Study of Total Scattering, Atmosphere-Basel, 6, 1069-1101, 2015.

Kolesar, K. R., Cellini, J., Peterson, P. K., Jefferson, A., Tuch, T., Birmili, W., Wiedensohler, A., and Pratt, K. A.: Effect of Prudhoe Bay emissions on atmospheric aerosol growth events observed in Utqiagvik (Barrow), Alaska, Atmos. Environ., 152, 146-155, 2017.

Kulmala, M., Vehkamaki, H., Petaja, T., Dal Maso, M., Lauri, A., Kerminen, V. M., Birmili, W., and McMurry, P. H.: Formation and growth rates of ultrafine atmospheric particles: a review of observations, J. Aerosol Sci., 35, 143-176, 2004.

Laaksonen, A., Kulmala, M., O’Dowd, C. D., Joutsensaari, J., Vaattovaara, P., Mikkonen, S., Lehtinen, K. E. J., Sogacheva, L., Dal Maso, M., Aalto, P., Petäjä, T., Sogachev, A., Yoon, Y. J., Lihavainen, H., Nilsson, D., Facchini, M. C., Cavalli, F., Fuzzi, S., Hoffmann, T., Arnold, F., Hanke, M., Sellegri, K., Umann, B., Junkermann, W., Coe, H., Allan, J. D., Alfarra, M. R., Worsnop, D. R., Riekkola, M.-L., Hyötyläinen, T., and Viisanen, Y.: The role of VOC oxidation products in continen- 
tal new particle formation, Atmos. Chem. Phys., 8, 2657-2665, https://doi.org/10.5194/acp-8-2657-2008, 2008.

Lance, S., Shupe, M. D., Feingold, G., Brock, C. A., Cozic, J., Holloway, J. S., Moore, R. H., Nenes, A., Schwarz, J. P., Spackman, J. R., Froyd, K. D., Murphy, D. M., Brioude, J., Cooper, O. R., Stohl, A., and Burkhart, J. F.: Cloud condensation nuclei as a modulator of ice processes in Arctic mixed-phase clouds, Atmos. Chem. Phys., 11, 8003-8015, https://doi.org/10.5194/acp11-8003-2011, 2011.

Leaitch, W. R., S. Sharma, Huang, L., Toom-Sauntry, D., Chivulescu, A., Macdonald, A. M., Salzen, K. v., Pierce, J. R., Bertram, A. K., Schroder, J. C., Shantz, N. C., Chang, R. Y.-W., and Norman, A.-L.: Dimethyl sulfide control of the clean summertime Arctic aerosol and cloud, Elementa, 1, https://doi.org/10.12952/journal.elementa.000017, 2013.

Leaitch, W. R., Korolev, A., Aliabadi, A. A., Burkart, J., Willis, M. D., Abbatt, J. P. D., Bozem, H., Hoor, P., Köllner, F., Schneider, J., Herber, A., Konrad, C., and Brauner, R.: Effects of $20-100 \mathrm{~nm}$ particles on liquid clouds in the clean summertime Arctic, Atmos. Chem. Phys., 16, 11107-11124, https://doi.org/10.5194/acp-16-11107-2016, 2016.

Liang, Q., Jaeglé, L., Jaffe, D. A., Weiss-Penzias, P., Heckman, A., and Snow, J. A.: Long-range transport of Asian pollution to the northeast Pacific: Seasonal variations and transport pathways of carbon monoxide, J. Geophys. Res.-Atmos., 109, D23S07, https://doi.org/10.1029/2003JD004402, 2004.

Liu, S., Aiken, A. C., Arata, C., Dubey, M. K., Stockwell, C. E., Yokelson, R. J., Stone, E. A., Jayarathne, T., Robinson, A. L., DeMott, P. J., and Kreidenweis, S. M.: Aerosol single scattering albedo dependence on biomass combustion efficiency: Laboratory and field studies, Geophys. Res. Lett., 41, 742-748, 2014.

Maahn, M., de Boer, G., Creamean, J. M., Feingold, G., McFarquhar, G. M., Wu, W., and Mei, F.: The observed influence of local anthropogenic pollution on northern Alaskan cloud properties, Atmos. Chem. Phys., 17, 14709-14726, https://doi.org/10.5194/acp-17-14709-2017, 2017.

McCluskey, C. S., DeMott, P. J., Prenni, A. J., Levin, E. J. T., McMeeking, G. R., Sullivan, A. P., Hill, T. C. J., Nakao, S., Carrico, C. M., and Kreidenweis, S. M.: Characteristics of atmospheric ice nucleating particles associated with biomass burning in the US: Prescribed burns and wildfires, J. Geophys. Res.Atmos., 119, 10458-10470, 2014.

McFarquhar, G. M., Ghan, S., Verlinde, J., Korolev, A., Strapp, J. W., Schmid, B., Tomlinson, J. M., Wolde, M., Brooks, S. D., Cziczo, D., Dubey, M. K., Fan, J., Flynn, C., Gultepe, I., Hubbe, J., Gilles, M. K., Laskin, A., Lawson, P., Leaitch, W. R., Liu, P., Liu, X., Lubin, D., Mazzoleni, C., Macdonald, A.-M., Moffet, R. C., Morrison, H., Ovchinnikov, M., Shupe, M. D., Turner, D. D., Xie, S., Zelenyuk, A., Bae, K., Freer, M., and Glen, A.: Indirect and Semi-direct Aerosol Campaign, B. Am. Meteorol. Soc., 92, 183-201, 2011.

Novakov, T. and Corrigan, C. E.: Cloud condensation nucleus activity of the organic component of biomass smoke particles, Geophys. Res. Lett., 23, 2141-2144, 1996.

Ødemark, K., Dalsøren, S. B., Samset, B. H., Berntsen, T. K., Fuglestvedt, J. S., and Myhre, G.: Short-lived climate forcers from current shipping and petroleum activities in the Arctic, Atmos. Chem. Phys., 12, 1979-1993, https://doi.org/10.5194/acp12-1979-2012, 2012.
Partain Jr., J. L., Alden, S., Strader, H., Bhatt, U. S., Bieniek, P. A., Brettschneider, B. R., Walsh, J. E., Lader, R. T., Olsson, P. Q., Rupp, T. S., R.L. Thoman, J., York, A. D., and Ziel, R. H.: An Assessment of the Role of Anthropogenic Climate Change in the Alaska Fire Season of 2015, B. Am. Meteorol. Soc., 97, S14-S18, 2016.

Parungo, F., Kopcewicz, B., Nagamoto, C., Schnell, R., Sheridan, P., Zhu, C., and Harris, J.: Aerosol-Particles in the Kuwait Oil Fire Plumes - Their Morphology, Size Distribution, ChemicalComposition, Transport, and Potential Effect on Climate, J. Geophys. Res.-Atmos., 97, 15867-15882, 1992.

Penner, J. E., Dickinson, R. E., and O'Neill, C. A.: Effects of Aerosol from Biomass Burning on the Global Radiation Budget, Science, 256, 1432-1434, 1992.

Persson, P. O. G., Fairall, C. W., Andreas, E. L., Guest, P. S., and Perovich, D. K.: Measurements near the Atmospheric Surface Flux Group tower at SHEBA: Near-surface conditions and surface energy budget, J. Geophys. Res.-Oceans, 107, SHE 21-21SHE 21-35, 2002.

Peters, G. P., Nilssen, T. B., Lindholt, L., Eide, M. S., Glomsrød, S., Eide, L. I., and Fuglestvedt, J. S.: Future emissions from shipping and petroleum activities in the Arctic, Atmos. Chem. Phys., 11, 5305-5320, https://doi.org/10.5194/acp-11-5305-2011, 2011.

Petters, M. D., Carrico, C. M., Kreidenweis, S. M., Prenni, A. J., DeMott, P. J., Collett, J. L., and Moosmüller, H.: Cloud condensation nucleation activity of biomass burning aerosol, J. Geophys. Res.-Atmos., 114, D22205, https://doi.org/10.1029/2009JD012353, 2009a.

Petters, M. D., Parsons, M. T., Prenni, A. J., DeMott, P. J., Kreidenweis, S. M., Carrico, C. M., Sullivan, A. P., McMeeking, G. R., Levin, E., Wold, C. E., Collett, J. L., and Moosmuller, H.: Ice nuclei emissions from biomass burning, J. Geophys. Res.-Atmos., 114, D07209, https://doi.org/10.1029/2008JD011532, 2009b.

Polissar, A. V., Hopke, P. K., and Harris, J. M.: Source Regions for Atmospheric Aerosol Measured at Barrow, Alaska, Environ. Sci. Technol., 35, 4214-4226, 2001.

Prenni, A. J., Demott, P. J., Rogers, D. C., Kreidenweis, S. M., Mcfarquhar, G. M., Zhang, G., and Poellot, M. R.: Ice nuclei characteristics from M-PACE and their relation to ice formation in clouds, Tellus B, 61, 436-448, 2009.

Quinn, P. K., Miller, T. L., Bates, T. S., Ogren, J. A., Andrews, E., and Shaw, G. E.: A 3-year record of simultaneously measured aerosol chemical and optical properties at Barrow, Alaska, J. Geophys. Res.-Atmos., 107, AAC 8-1-AAC 8-15, 2002.

Quinn, P. K., Bates, T. S., Schulz, K., and Shaw, G. E.: Decadal trends in aerosol chemical composition at Barrow, Alaska: 1976-2008, Atmos. Chem. Phys., 9, 8883-8888, https://doi.org/10.5194/acp-9-8883-2009, 2009.

Raatz, W. E. and Shaw, G. E.: Long-Range Tropospheric Transport of Pollution Aerosols into the Alaskan Arctic, J. Clim. Appl. Meteorol., 23, 1052-1064, 1984.

Randerson, J. T., Liu, H., Flanner, M. G., Chambers, S. D., Jin, Y., Hess, P. G., Pfister, G., Mack, M. C., Treseder, K. K., Welp, L. R., Chapin, F. S., Harden, J. W., Goulden, M. L., Lyons, E., Neff, J. C., Schuur, E. A. G., and Zender, C. S.: The Impact of Boreal Forest Fire on Climate Warming, Science, 314, 1130-1132, 2006.

Rissler, J., Vestin, A., Swietlicki, E., Fisch, G., Zhou, J., Artaxo, P., and Andreae, M. O.: Size distribution and hygro- 
scopic properties of aerosol particles from dry-season biomass burning in Amazonia, Atmos. Chem. Phys., 6, 471-491, https://doi.org/10.5194/acp-6-471-2006, 2006.

Roiger, A., Thomas, J.-L., Schlager, H., Law, K. S., Kim, J., Schäfler, A., Weinzierl, B., Dahlkötter, F., Krisch, I., Marelle, L., Minikin, A., Raut, J.-C., Reiter, A., Rose, M., Scheibe, M., Stock, P., Baumann, R., Bouarar, I., Clerbaux, C., George, M., Onishi, T., and Flemming, J.: Quantifying Emerging Local Anthropogenic Emissions in the Arctic Region: The ACCESS Aircraft Campaign Experiment, B. Am. Meteorol. Soc., 96, 441460, 2015.

Sakamoto, K. M., Allan, J. D., Coe, H., Taylor, J. W., Duck, T. J., and Pierce, J. R.: Aged boreal biomass-burning aerosol size distributions from BORTAS 2011, Atmos. Chem. Phys., 15, 16331646, https://doi.org/10.5194/acp-15-1633-2015, 2015.

Schnell, R. C. and Raatz, W. E.: Vertical and horizontal characteristics of Arctic haze during AGASP: Alaskan Arctic, Geophys. Res. Lett., 11, 369-372, 1984.

Screen, J. A. and Simmonds, I.: The central role of diminishing sea ice in recent Arctic temperature amplification, Nature, 464, 1334-1337, 2010.

Sedlacek, A. J.: Arctic Black Carbon Loading and Profile Using the Single-Particle Soot Photometer (SP2) Field Campaign Report, U.S. Department of Energy, Office of Science, Office of Biological and Environmental Research, 2016.

Serreze, M. C. and Barry, R. G.: Processes and impacts of Arctic amplification: A research synthesis, Global Planet. Change, 77, 85-96, 2011.

Serreze, M. C. and Francis, J. A.: The arctic amplification debate, Climatic Change, 76, 241-264, 2006.

Stein, A. F., Draxler, R. R., Rolph, G. D., Stunder, B. J. B., Cohen, M. D., and Ngan, F.: NOAA's HYSPLIT Atmospheric Transport and Dispersion Modeling System, B. Am. Meteorol. Soc., 96, 2059-2077, 2015.

Stohl, A., Andrews, E., Burkhart, J. F., Forster, C., Herber, A., Hoch, S. W., Kowal, D., Lunder, C., Mefford, T., Ogren, J. A., Sharma, S., Spichtinger, N., Stebel, K., Stone, R., Strom, J., Torseth, K., Wehrli, C., and Yttri, K. E.: Pan-Arctic enhancements of light absorbing aerosol concentrations due to North American boreal forest fires during summer 2004, J. Geophys. Res.-Atmos., 111, D22214, https://doi.org/10.1029/2006JD007216, 2006.
Stohl, A., Klimont, Z., Eckhardt, S., Kupiainen, K., Shevchenko, V. P., Kopeikin, V. M., and Novigatsky, A. N.: Black carbon in the Arctic: the underestimated role of gas flaring and residential combustion emissions, Atmos. Chem. Phys., 13, 8833-8855, https://doi.org/10.5194/acp-13-8833-2013, 2013.

Tsay, S.-C., Stamnes, K., and Jayaweera, K.: Radiative Energy Budget in the Cloudy and Hazy Arctic, J. Atmos. Sci., 46, 10021018, 1989.

Verlinde, J., Harrington, J. Y., Yannuzzi, V. T., Avramov, A., Greenberg, S., Richardson, S. J., Bahrmann, C. P., McFarquhar, G. M., Zhang, G., Johnson, N., Poellot, M. R., Mather, J. H., Turner, D. D., Eloranta, E. W., Tobin, D. C., Holz, R., Zak, B. D., Ivey, M. D., Prenni, A. J., DeMott, P. J., Daniel, J. S., Kok, G. L., Sassen, K., Spangenberg, D., Minnis, P., Tooman, T. P., Shupe, M., Heymsfield, A. J., and Schofield, R.: The Mixed-Phase Arctic Cloud Experiment, B. Am. Meteorol. Soc., 88, 205-221, 2007.

Warneck, P.: Chemistry of the Natural Atmosphere, Academic Press, Cambridge, MA, 1999.

Wiedinmyer, C., Akagi, S. K., Yokelson, R. J., Emmons, L. K., AlSaadi, J. A., Orlando, J. J., and Soja, A. J.: The Fire INventory from NCAR (FINN): a high resolution global model to estimate the emissions from open burning, Geosci. Model Dev., 4, 625641, https://doi.org/10.5194/gmd-4-625-2011, 2011.

Wilson, J. C. and McMurry, P. H.: Studies of aerosol formation in power plant plumes - II. Secondary aerosol formation in the Navajo generating station plume, Atmos. Environ., 15, 23292339, 1981.

Wilson, W. E. and Suh, H. H.: Fine Particles and Coarse Particles: Concentration Relationships Relevant to Epidemiologic Studies, J. Air Waste Manage., 47, 1238-1249, 1997. 